\title{
The 6 August 2010 Mount Meager rock slide-debris flow, Coast Mountains, British Columbia: characteristics, dynamics, and implications for hazard and risk assessment
}

\author{
R. H. Guthrie ${ }^{1}$, P. Friele ${ }^{2}$, K. Allstadt ${ }^{3}$, N. Roberts ${ }^{4}$, S. G. Evans ${ }^{5}$, K. B. Delaney ${ }^{5}$, D. Roche ${ }^{6}$, J. J. Clague $^{4}$, and \\ M. Jakob ${ }^{7}$ \\ ${ }^{1} \mathrm{MDH}$ Engineered Solutions, SNC-Lavalin Group, Calgary, AB, Canada \\ ${ }^{2}$ Cordilleran Geoscience, Squamish, BC, Canada \\ ${ }^{3}$ Earth and Space Sciences, University of Washington, Seattle, WA, USA \\ ${ }^{4}$ Centre for Natural Hazard Research, Simon Fraser University, Burnaby, BC, Canada \\ ${ }^{5}$ Landslide Research Programme, University of Waterloo, Waterloo, ON, Canada \\ ${ }^{6}$ Kerr Wood Leidal Associates Limited, Burnaby, BC, Canada \\ ${ }^{7}$ BGC Engineering Inc., Vancouver, BC, Canada
}

Correspondence to: R. H. Guthrie (rguthrie@mdhsolutions.com)

Received: 14 October 2011 - Revised: 7 February 2012 - Accepted: 3 March 2012 - Published: 4 May 2012

\begin{abstract}
A large rock avalanche occurred at 03:27:30 PDT, 6 August 2010, in the Mount Meager Volcanic Complex southwest British Columbia. The landslide initiated as a rock slide in Pleistocene rhyodacitic volcanic rock with the collapse of the secondary peak of Mount Meager. The detached rock mass impacted the volcano's weathered and saturated flanks, creating a visible seismic signature on nearby seismographs. Undrained loading of the sloping flank caused the immediate and extremely rapid evacuation of the entire flank with a strong horizontal force, as the rock slide transformed into a debris flow. The disintegrating mass travelled down Capricorn Creek at an average velocity of $64 \mathrm{~m} \mathrm{~s}^{-1}$, exhibiting dramatic super-elevation in bends to the intersection of Meager Creek, $7.8 \mathrm{~km}$ from the source. At Meager Creek the debris impacted the south side of Meager valley, causing a runup of $270 \mathrm{~m}$ above the valley floor and the deflection of the landslide debris both upstream (for $3.7 \mathrm{~km}$ ) and downstream into the Lillooet River valley (for $4.9 \mathrm{~km}$ ), where it blocked the Lillooet River river for a couple of hours, approximately $10 \mathrm{~km}$ from the landslide source. Deposition at the Capricorn-Meager confluence also dammed Meager Creek for about $19 \mathrm{~h}$ creating a lake $1.5 \mathrm{~km}$ long. The overtopping of the dam and the predicted outburst flood was the basis for a night time evacuation of 1500 residents in the town of Pemberton, $65 \mathrm{~km}$ downstream. High-resolution GeoEye satellite imagery obtained on 16 October 2010 was used to create a post-event digital elevation model. Comparing
\end{abstract}

pre- and post-event topography we estimate the volume of the initial displaced mass from the flank of Mount Meager to be $48.5 \times 10^{6} \mathrm{~m}^{3}$, the height of the path $(H)$ to be $2183 \mathrm{~m}$ and the total length of the path $(L)$ to be $12.7 \mathrm{~km}$. This yields $H / L=0.172$ and a fahrböschung (travel angle) of $9.75^{\circ}$. The movement was recorded on seismographs in British Columbia and Washington State with the initial impact, the debris flow travelling through bends in Capricorn Creek, and the impact with Meager Creek are all evident on a number of seismograms. The landslide had a seismic trace equivalent to a $M=2.6$ earthquake. Velocities and dynamics of the movement were simulated using DAN-W. The 2010 event is the third major landslide in the Capricorn Creek watershed since 1998 and the fifth large-scale mass flow in the Meager Creek watershed since 1930. No lives were lost in the event, but despite its relatively remote location direct costs of the 2010 landslide are estimated to be in the order of $\$ 10$ M CAD.

\section{Introduction}

At 03:27 local time (PDT), on 6 August 2010, a $48.5 \times 10^{6} \mathrm{~m}^{3}$ landslide was initiated on Mount Meager, at $50.623^{\circ} \mathrm{N} / 123.501^{\circ} \mathrm{W}$ in the Coast Mountains of British Columbia (Fig. 1). The landslide originated with the collapse of the southern peak of Mount Meager (2554 m a.s.1.)

Published by Copernicus Publications on behalf of the European Geosciences Union. 


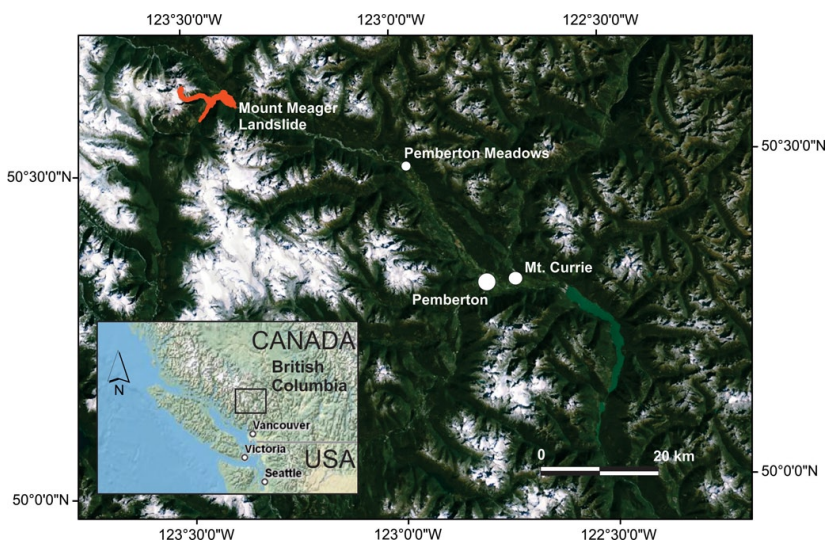

Fig. 1. Location map of the Mount Meager landslide. Three communities lie down-valley from the Mount Meager complex (at the head of the landslide): Pemberton Meadows at about $32 \mathrm{~km}$, Pemberton at about $65 \mathrm{~km}$, and Mt. Currie just beyond that.

onto the saturated flank of the mountain where it incorporated a significant volume of material, forming a highly mobile, very rapid debris flow (Fig. 2). The landslide travelled downslope at high velocity over Capricorn Glacier, and then down the entire $7 \mathrm{~km}$ length of Capricorn Creek. At the mouth of Capricorn Creek the landslide debris encountered the opposing wall of the Meager Creek - Capricorn Creek confluence; causing a dramatic split in the moving debris that travelled both upstream, filling and damming Meager Creek, and downstream into the wider Lillooet River valley, where it briefly dammed the Lillooet River.

This landslide is significant in that it is one of the largest to have occurred worldwide since 1945 and is one of the three largest to have occurred in the Canadian Cordillera in historical time (Evans, 2006; Guthrie and Evans, 2007; Lipovsky et al., 2008). Though there were no deaths or serious injuries associated with the event, approximately 1500 people were evacuated from their homes as part of the emergency response in anticipation of the outburst of a landslide dam that formed in Meager Creek as a result of the landslide. Landslides from the Mount Meager Volcanic Complex (MMVC) have the potential to impact nearby communities, including the village of Pemberton, a town of slightly more than 2100 people, approximately $65 \mathrm{~km}$ southeast of the MMVC, and rural communities along the Lillooet River.

In this paper we summarize the main characteristics (initial failure, subsequent behaviour, and landslide damming) of the 6 August 2010 landslide. We examine the dynamics of the landslide interpreted from seismic records, and its behaviour as simulated in a dynamic analysis model (DAN-W) for velocity and extent of motion. This report is based on data acquired during field work both immediately after the event and over subsequent months, as well as data from postevent high resolution satellite imagery.

\section{The Mount Meager volcanic complex}

\subsection{Geology and geomorphology}

Mount Meager is located in the Province of British Columbia, $150 \mathrm{~km}$ north of Vancouver and approximately $65 \mathrm{~km}$ northwest of the town of Pemberton (Fig. 1). It is part of the MMVC, which consists of about $20 \mathrm{~km}^{3}$ of volcanic rocks, ranging in age from Pliocene to Holocene (Read, 1978, 1990). The MMVC lies at the northern limit of the Cascade magmatic arc, which includes other prominent volcanoes in the Pacific Northwest such as Mounts Baker, Rainier, and St. Helens in Washington State, Mount Hood in Oregon, and Mount Shasta in California. Volcanic activity at these centers is a product of subduction of the oceanic Juan de Fuca plate beneath continental North America (Hickson, 1994).

The MMVC consists of several coalesced stratovolcanoes, of which Mount Meager is the youngest. The oldest known eruption dates to approximately 2.2 Ma ago; the youngest eruption occurred about 2350 years ago (Clague et al., 1995) near the northeast flank of Plinth Peak, when a rhyodacitic welded ash tuff and lava flow blocked Lillooet River (Read, 1990; Stasiuk et al., 1996; Stewart 2002), and produced a pumiceous air fall deposit across part of southern British Columbia and into westernmost Alberta (Nasmith et al., 1967; Westgate and Dreimanis, 1967).

The MMVC consists of highly fractured, weak, and hydrothermally altered volcanic rocks (Read, 1990), the lowermost of which were assigned by Read (1978) to the Capricorn Formation, which comprises $200 \mathrm{~m}$ of porphyritic rhyodacite breccia and tuff, and $200 \mathrm{~m}$ of porphyritic rhyodacite flows. Above the Capricorn Formation and forming the steep summit flank is a porphyritic dacite plug of the Plinth Formation. The extrusive units support inclined flow layering dipping $35-65^{\circ}$ to the east-southeast.

Groundwater daylights in the MMVC as hot springs and bedrock seeps, and the lowermost extrusive rocks of the Capricorn Formation and portions of the intrusive plug have been hydrothermally altered to an ochre colour.

All except perhaps the top of Mount Meager was covered by the Cordilleran ice sheet during the last Pleistocene glaciation (Clague, 1981). Glacial erosion, followed by deglaciation between about 14000 and $11000 \mathrm{yr}$ ago, subsequent advances of alpine glaciers, twentieth-century thinning and retreat of glaciers and recent thaw of alpine permafrost have all contributed to widespread instability within the massif (Holm et al., 2004). A small glacier is located at the head of Capricorn Creek adjacent to the source slope of the 2010 landslide. It was much more extensive during the Little Ice Age than today, extending across the lower part of the failed slope and about $2.5 \mathrm{~km}$ down Capricorn Creek (Holm et al., 2004). The glacier scoured and steepened valley sides in the upper part of the valley, and an apron of sediments accumulated against the ice beneath the summit flank. 

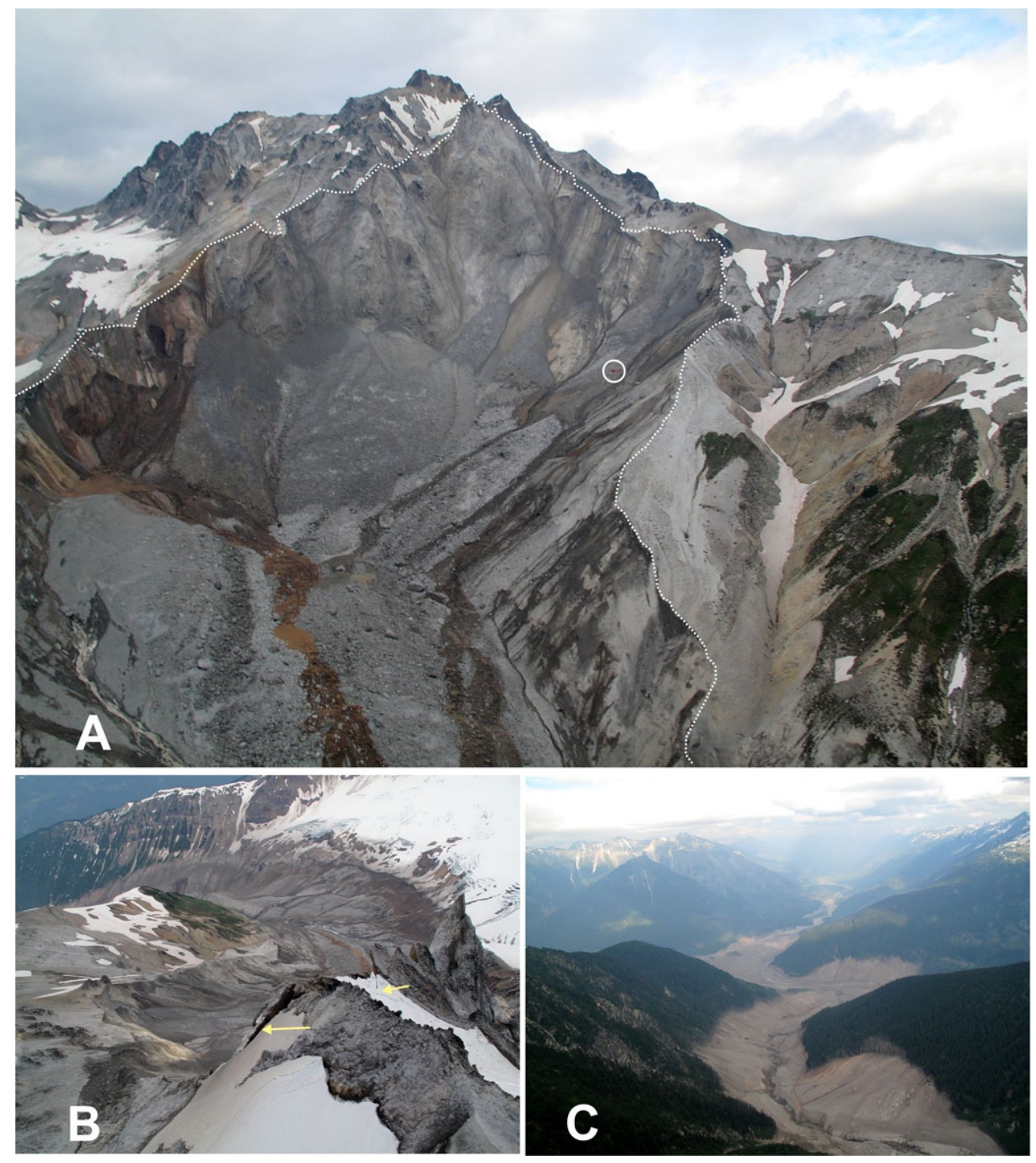

Fig. 2. The $48.5 \times 10^{6} \mathrm{~m}^{3}$ rock slide - debris flow from Mount Meager, August 06, 2010. The outline of the initial failure is shown in (A) as a white dashed line. The landslide is approximately south-facing. The lateral shear surfaces are approximately 70 vertical meters high; a helicopter provides scale (inside the white circle). Note the considerable groundwater emerging through weathered bedrock on the western margin and from several other places including the vertical bedrock backscarp. A remnant of the south peak of Mount Meager remains at the apex of the backscarp, where tension cracks persist (some visible in B). Ongoing rock fall from the remaining peak and the sidewalls continued for several months after the main event. The immediate run-out, viewed from the peak looking down, around the first bend of Capricorn Creek is shown in (B). The full extent of the landslide is very difficult to see in any single picture, but $(\mathbf{C})$ gives a sense of the extent to which the run-out inundated several valleys.

Subsequent thinning and retreat of the glacier debutressed the sidewalls in the upper part of the catchment, inducing instability (Holm et al., 2004).

\subsection{Landslide history}

The MMVC is arguably the most landslide-prone region in Canada (Friele et al., 2008; Friele and Clague 2009); at least 25 landslides $\geq 0.5 \times 10^{6} \mathrm{~m}^{3}$ are known to have occurred in the last $10000 \mathrm{yr}$ (Table 1). Numerous landslides, less than
$0.5 \times 10^{6} \mathrm{~m}^{3}$ in volume, have been identified from Mount Meager (Jordan, 1994; Jakob, 1996). However, such an inventory is unlikely to be complete even in historical times, and a sampling bias is certain to occur. At the same time, it is likely that several large prehistoric landslides have occurred that have not yet been identified, and thus the prehistoric inventory should not be considered complete. 
Table 1. The history of landslides $\geq 0.5 \times 10^{6} \mathrm{~m}^{3}$ from the Mount Meager Complex (adapted and updated from Friele et al., 2008).

\begin{tabular}{|c|c|c|c|c|}
\hline Event & Source & Date $^{1}$ & $\begin{array}{r}\text { Volume }^{2} \\
\left(\times 10^{6} \mathrm{~m}^{3}\right)\end{array}$ & Reference \\
\hline \multicolumn{5}{|l|}{ Prehistoric } \\
\hline Rock avalanche/debris flow & Pylon Pk. & -7900 & $450^{*}$ & Friele and Clague (2004) \\
\hline Rock avalanche/debris flow & Job Ck. & -6250 & $500^{*}$ & Friele et al. (2005) \\
\hline Rock avalanche/debris flow & Capricorn $\mathrm{Ck}$. & -5250 & $5^{*}$ & McNeely and McCuaig (1991) \\
\hline $\begin{array}{l}\text { Rock avalanche/debris } \\
\text { flow/hyper concentrated flow }\end{array}$ & Pylon Pk & -4400 & 200 & $\begin{array}{l}\text { Friele and Clague (2004); } \\
\text { Friele et al. (2005) }\end{array}$ \\
\hline Rock avalanche/debris flow & Job Ck. & -2600 & $500^{*}$ & Friele et al. (2005); Simpson et al. (2006) \\
\hline Pyroclastic flow & Syn-eruptive & -2400 & 440 & Stasiuk et al. (1996); Stewart (2002) \\
\hline $\begin{array}{l}\text { Rock avalanche/outburst } \\
\text { flood/debris flow/hyper } \\
\text { concentrated flow }\end{array}$ & Syn-eruptive & -2400 & 200 & Stasiuk et al. (1996); Stewart (2002) \\
\hline Rock avalanche & Syn- to post-eruptive & -2400 & 44 & Stasiuk et al. (1996); Stewart (2002) \\
\hline Debris flow & Devastation Ck. & -2170 & 12 & McNeely and McCuaig (1991) \\
\hline Debris flow & Job Ck. & -2240 & 1 & Friele et al. (2008) \\
\hline Debris flow & Angel Ck. & -1920 & $0.5^{*}$ & McNeely and McCuaig (1991) \\
\hline Debris flow & Job Ck. & -1860 & 1 & McNeely and McCuaig (1991) \\
\hline Debris flow & Job Ck. & -870 & $9^{*}$ & Jordan (1994) \\
\hline Debris flow & Job Ck. & -630 & 1 & Friele et al. (2008) \\
\hline Debris flow & No Good Ck. & -370 & $5^{*}$ & McNeely and McCuaig (1991) \\
\hline \multicolumn{5}{|l|}{ Historic (age AD) } \\
\hline Debris flow & Capricorn Ck. & 1850 & 1.3 & $\begin{array}{l}\text { Jakob (1996); McNeely and } \\
\text { McCuaig (1991) }\end{array}$ \\
\hline Debris flow & Capricorn Ck. & 1903 & 30 & Jakob (1996) \\
\hline Debris flow & Devastation Ck. & 1931 & 3 & $\begin{array}{l}\text { Carter (1932); Decker et al. (1977); } \\
\text { Jordan (1994) }\end{array}$ \\
\hline Rock avalanche & Capricorn Ck. & 1933 & $0.5^{*}$ & Croft $(1983)$ \\
\hline Rock avalanche & Devastation $\mathrm{Ck}$. & 1947 & 3 & Evans unpublished data \\
\hline Rock avalanche & Devastation $\mathrm{Ck}$. & 1975 & 12 & Mokievsky-Zubok (1977); Evans (2001) \\
\hline Rock avalanche & Mt. Meager & 1986 & $0.5^{*}$ & Evans (1987) \\
\hline Debris flow & Capricorn $\mathrm{Ck}$. & 1998 & 1.3 & Bovis and Jakob (2000) \\
\hline Debris flow & Capricorn $\mathrm{Ck}$. & 2009 & 0.5 & Friele (unpublished data) \\
\hline Rock slide/debris flow & Capricorn Ck. & 2010 & 48.5 & This study \\
\hline
\end{tabular}

${ }^{1}$ Prehistoric dates are radiocarbon ages BP. Cited ages are those that closely constrain an event, however, considerable ranges may be present. For more details see Friele and Clague (2004), or the original sources. ${ }^{2}$ Volumes denoted by * are the median volume of a wider range.

\section{The 6 August 2010 Mount Meager landslide}

\subsection{Initial failure}

The 2010 Mount Meager landslide originated with the collapse of its southern peak ( $2554 \mathrm{~m}$ a.s.l.) onto its failing saturated flank where it incorporated a significant volume of material, forming a highly mobile, very rapid debris flow. The debris flow travelled the entire $7 \mathrm{~km}$ length of Capricorn Creek and inundated both the Meager Creek valley and the Lillooet River valley.

The overall path height $(\mathrm{H})$ is $2183 \mathrm{~m}$ and the total path length $(L)$ is $12.7 \mathrm{~km}$. This yields $H / L$ of 0.172 and a fahrböschung (travel angle) of $9.75^{\circ}$ (Fig. 3).
The landslide had no distinct seismic or meteorological trigger but was recorded on seismographs in British Columbia and Washington State. It occurred as a result of several important preconditions. The Mount Meager Volcanic Complex is subject to frequent landslide activity indicating conditions especially favourable to large-scale slope movement. These conditions include poor quality or structurally weak volcanic and volcaniclastic bedrock, a Holocene history of glacial unloading, recent explosive volcanism, and Little Ice Age glacial activity (slope loading, unloading, and over-steepening).

Evidence indicates that groundwater played a key role in the 2010 failure. Prior to failure the flanks of Mount Meager were subject to high pore pressures indicated by extensive 


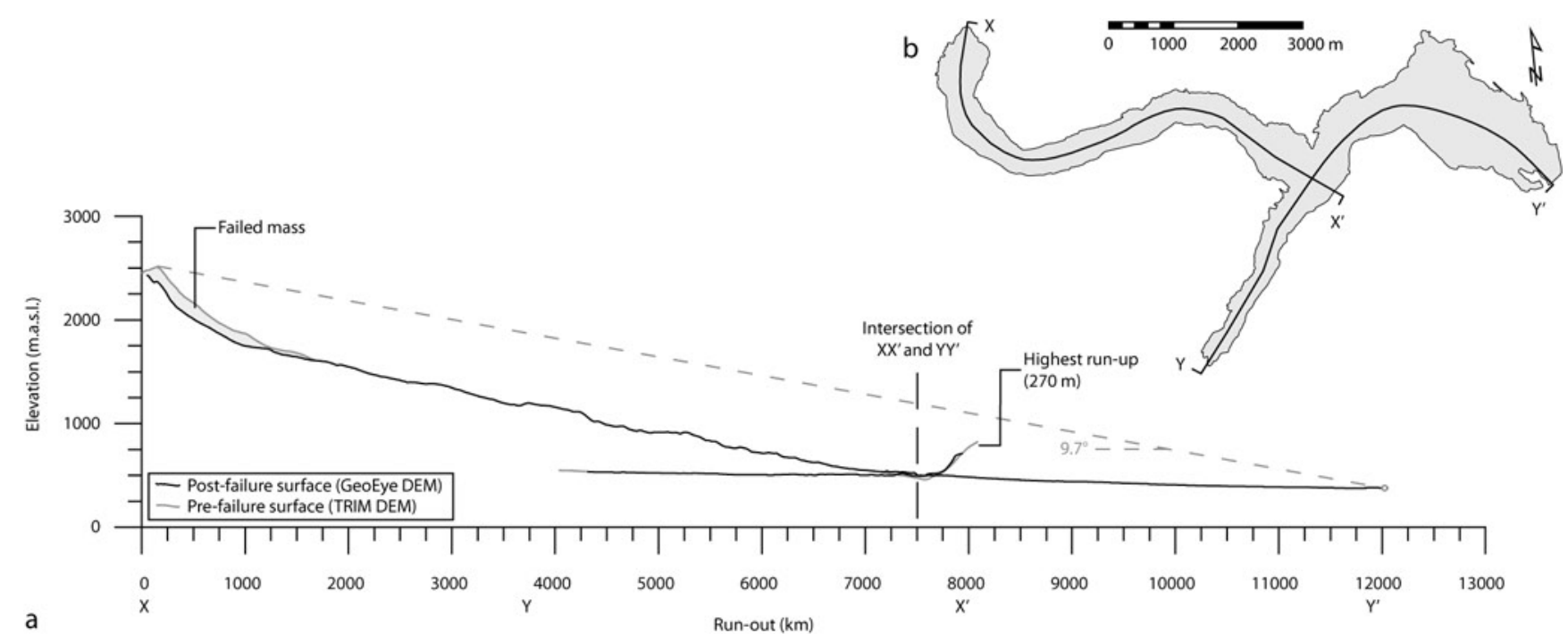

Fig. 3. Profile of the Mount Meager landslide.

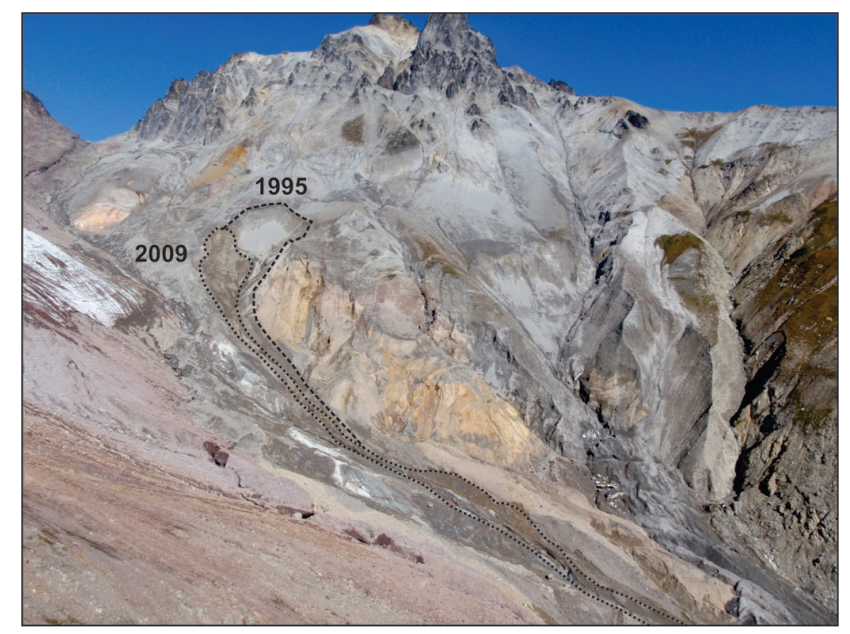

Fig. 4. Mount Meager before the 2010 landslide. The sources and upper paths of the 2009 and 1995 Mount Meager debris flows are outlined and coincide roughly with the present-day location of the lateral shear. The darker colour of the 2009 event is from groundwater saturation, and the orange staining of rock on the lower slopes indicates long-term exposure to high groundwater levels and hydrothermally altered volcanic rock (photograph by Dave Southam).

surface seepage observed throughout the failure surface and along the lateral shears following the 2010 event (Fig. 2a). The largest visible bedrock spring occurred along the west lateral scarp and was the location of at least two previous landslides, occurring in 2009 and 1998 (Fig. 4). Water supply was exacerbated by summer melt of snow and ice, causing even greater saturation of slopes.

Based on our interpretation of seismic records (see below), initial failure is thought to have begun as a series of major rock falls from the high secondary peak, or gendarme, of
Mount Meager, beginning at 03:27:30 h (PDT) on the morning of 6 August 2010. The rock falls fell approximately $500 \mathrm{~m}$ onto the weak and heavily saturated south flank of Mount Meager which then began to disintegrate as it was subjected to impact-generated undrained loading. On the seismic record (see below) the impact of the collapsed peak was measured less than 45 seconds after the first movements and resulted in the extremely rapid horizontal displacement of the materials composing the flank. Interpretation of seismic records (see below) indicates that the material left the initiation zone at a velocity of approximately $87 \mathrm{~m} \mathrm{~s}^{-1}$, leaving behind distinct lateral scarps and a high vertical bedrock head scarp (Fig. 2).

\subsection{Landslide volume analysis}

A robust volume analysis of the initial failure mass was accomplished by comparing pre- and post-event digital elevation models (DEMs) of the landslide (Fig. 5). Topographic data representing the pre-event surface was obtained from a $25 \mathrm{~m}$ resolution Terrain Resource Inventory Mapping (TRIM) DEM, the British Columbia provincial standard base map. The post-event surface (DEM) was created using two sets of $5 \mathrm{~m}$ resolution GeoEye stereo images obtained $22 \mathrm{Au}-$ gust and 21 September 2010.

Each DEM represents a surface model that, while internally consistent, may contain differences due to image offsets, resolution, and ground control points. GeoEye used only the satellite telemetry for control, and was therefore projected in space slightly above the surface represented by the TRIM DEM. This was corrected by overlaying the GeoEye surface onto the TRIM surface, so that the average difference in ground elevations outside the landslide track was zero. 


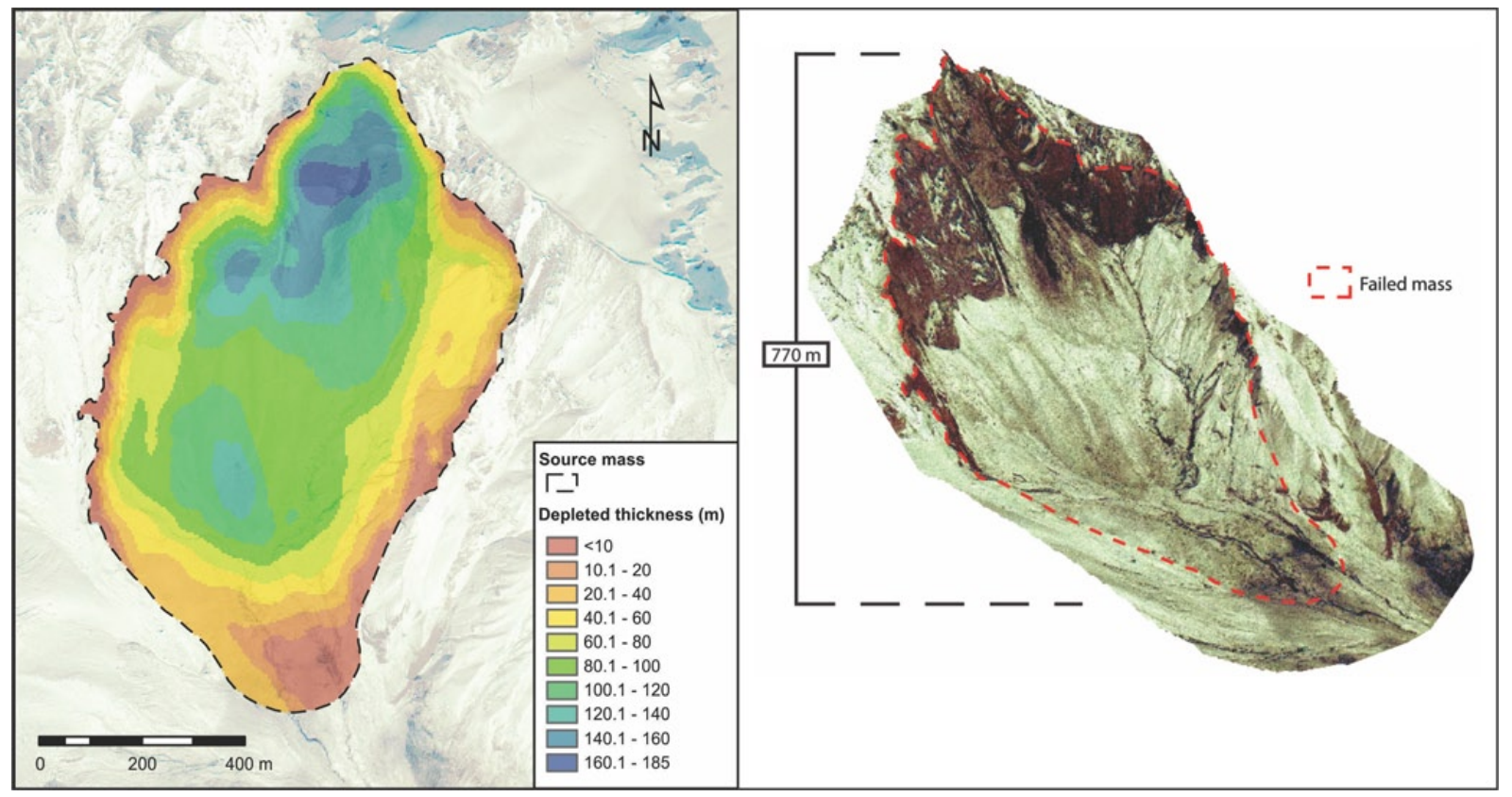

Fig. 5. The difference in depth between the TRIM (before) and GeoEye DEMs used to calculate volume. The strong lateral shears, high backscarp and bulge of the pre-failure flank are all readily interpreted from the differencing map. The landslide outline was accurately delineated based on new imagery (right side of figure). The total calculated volume is $48.5 \times 10^{6} \mathrm{~m}^{3}$.

A difference calculation was then performed on the two surfaces inside the landslide track, using raster math in a Geographic Information System (GIS), and summing the total difference for each pixel in the initiation zone. The resulting volume calculated for the initial failure is $48.5 \times 10^{6} \mathrm{~m}^{3}$.

Field estimates of deposit thickness were made at several locations following the landslide, then matched to morphological units, and corroborated by comparing cross sections of the TRIM DEM with the GeoEye DEM. The total volume of the deposit was calculated at $41 \times 10^{6} \mathrm{~m}^{3}$, including bulking. The volume estimate from the field is about $15 \%$ lower than expected, or, if approximately $6 \mathrm{M} \mathrm{m}^{3}$ of bulking is estimated, then it represents a difference of almost $30 \%$.

Several explanations may be considered: (1) the initial volume is from a limited area $\left(\sim 0.4 \mathrm{~km}^{2}\right)$ of exceptionally deep scour. It is not particularly sensitive to a change in depth of a few meters; however, it is sensitive to even a small shift in the outline of the initiation zone. Fortunately, this error is controllable in the production of an accurate outline of the head scarp (Fig. 5). In contrast, the deposit volume was determined across a broad area and it is therefore about $20 \times$ more sensitive to a change in depth estimation. (2) The volume estimation of the deposit, involved considerably more subjective analysis and expert judgement at each point across a landscape that was $\sim 9 \mathrm{~km}^{2}$. To minimize this, cross-sections of the two surfaces were also used in careful corroboration of field estimates. (3) The volume contained in Capricorn valley, V-shaped in 2009 and now truncated in profile with new deposition in 2010 was underestimated.
(4) The TRIM DEM was built in 1987. Several geomorphological events have occurred since then that could each affect the valley bottom, but not substantially affect the initiation zone, resulting in a real-life surface that was different than the DEM. These events include two previous landslides in Capricorn Creek (1998 and 2009), and ongoing reworking of material from Meager Creek, Capricorn Creek and Lillooet River, since 1987. With these limitations in mind, we consider the deposit volume to be in reasonable agreement with the initial volume.

Our estimate of the initial volume of the 2010 Mount Meager landslide is thus approximately $48.5 \times 10^{6} \mathrm{~m}^{3}$. With this volume it is one of the largest landslides to have occurred worldwide since 1945 (Evans, 2006) and one of the three largest landslides to have occurred in the Canadian Cordillera in historical time. It is comparable in volume to the 1965 Hope Slide (Mathews and McTaggart, 1978).

We note that the characteristics of the 6 August Mount Meager event are largely depositional outside of the initiation zone.

\subsection{Transformation into debris flow and run out}

The disintegrated landslide mass left the initiation zone in a largely horizontal trajectory and traversed Capricorn Glacier, causing almost no damage to the glacier itself (note the drainage features of Capricorn Glacier, perpendicular to the landslide flow, in Fig. 6a), and flowed into the first bend of the Capricorn Creek valley (Fig. 6b). By this time the 


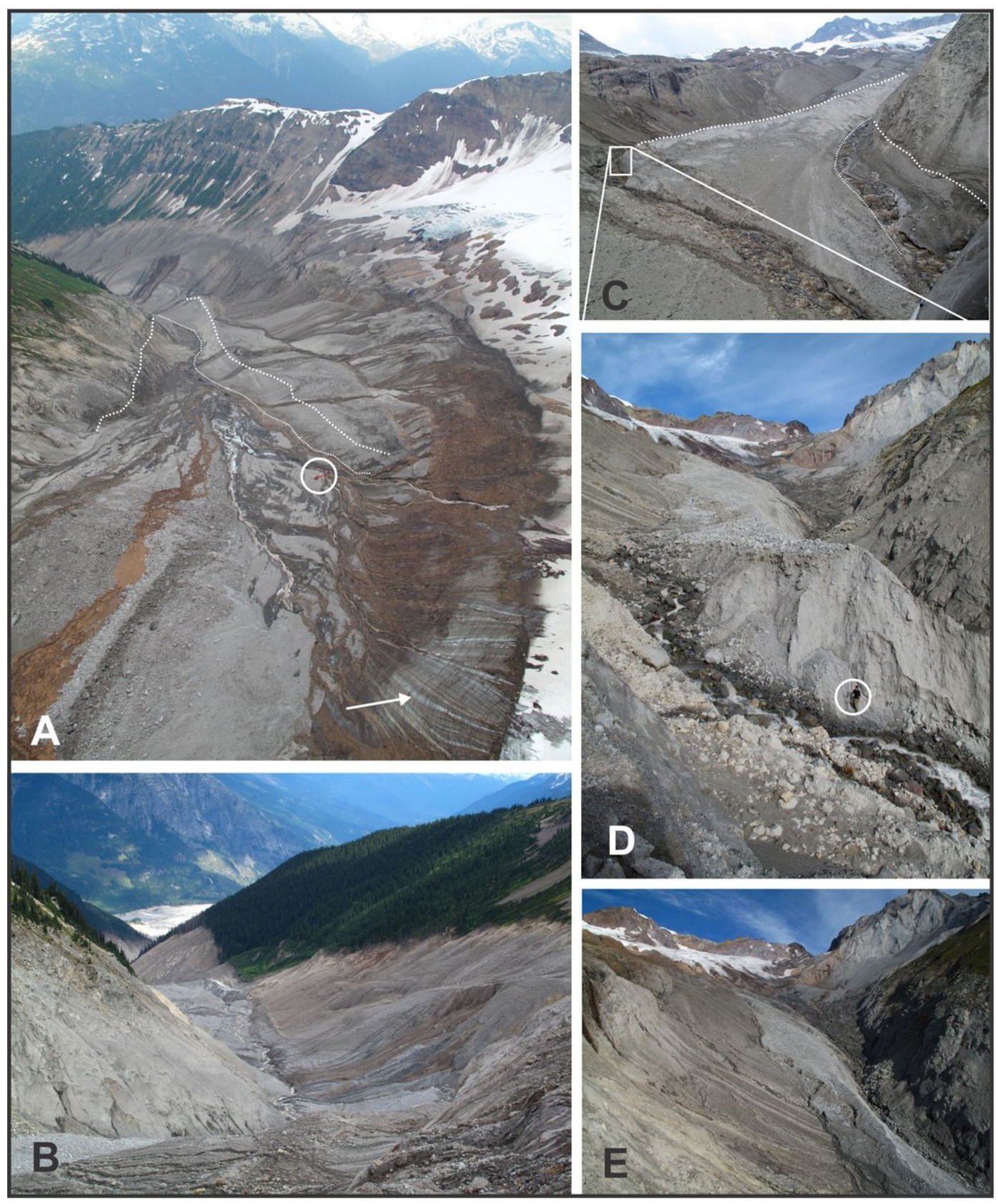

Fig. 6. Looking down the initial landslide path (helicopter in white circle for scale). Note the ice of Capricorn Glacier, intact with longitudinal melt lines perpendicular to the direction of flow (A). Overspray is evident beyond the path edge, particularly on the snow. The lower portion of the valley was in-filled by deposits from the avalanche, which was subsequently evacuated along the left side of the valley (shown by white dotted lines) in one or more liquid slurries. Looking further down the landslide run-out, through the first bend (B), deposition is evident even on the valley sidewalls. Images (C) and (D) show valley floor deposition as viewed from below and (E) looks back up at the initiation zone. White dotted lines in $(\mathbf{C})$ correspond to those in A and the white circle in (D) shows a person for scale. Ice persists in the valley floor at the base of the deposit (A) and remains largely undamaged, though directly over-ridden (indicated by white arrow).

landslide was typical of a debris flow as the initial failure mass had completely disintegrated and had become fluidised by mixing with the pore water contained in the failed mass.

We interpret the rapid transformation to a debris flow to be a consequence of: (1) elevated groundwater conditions leading up to the event; (2) poor rock quality caused by prolonged exposure to hydrothermally derived groundwater for years prior to the event; (3) the sudden transfer of energy from the collapse of the mountain peak; and (4) a rapid increase in hydrostatic pressure as a result of the impact (undrained loading of the slope). 


\subsection{Analysis and interpretation of seismic signature}

The Meager Creek landslide generated long-period seismic waves that were visible at stations from southern California to northern Alaska, up to $2800 \mathrm{~km}$ away. A sample of vertical-component broadband seismograms of this event is displayed on Fig. 7. No known earthquake was associated with the failure, but the event itself was assigned an equivialent local magnitude of 2.6 by the Canadian Seismic Network. Landslides are distinguished from seismic signals by a characteristically high ratio of long period to short period energy waves (Weichert et al., 1994; McSaveney and Downes, 2002). The long-period surface waves generated by the Mount Meager event were much stronger than would be expected from an earthquake of the same magnitude.

Landslides do not always generate identifiable seismic signatures due in part to their slower source process and poor ground coupling as compared to earthquakes. Seismic energy conversion rates for similar events are estimated to be as low as $0.01 \%$ of the kinetic energy and $1 \%$ of the potential energy released by the slide (Berrocal et al., 1978). It requires an extremely energetic source to generate waves high enough in amplitude to be visible for thousands of kilometers. The seismogenic nature of this landslide is a result of the large volume of material involved and the extremely rapid velocities.

The seismic signal recorded from the Mount Meager landslide can be examined in two frequency bands to separate the waves coming from different sources. Figure 8 is a plot of the vertical component seismogram and envelope for two frequency bands at the closest station, WSLR, a threecomponent broadband station. This station is operated by the Canadian National Seismograph Network, located $70 \mathrm{~km}$ southeast of Mount Meager. The signal is filtered to separate the short period and long period waves, and also plotted as an envelope to show the overall shape of a signal by including only the amplitude information from the seismogram. This is helpful in picking arrivals and separating sources that cannot easily be seen in the seismogram. The long-period portion, filtered to include only frequencies below $0.2 \mathrm{~Hz}$ ( $>5 \mathrm{~s}$ period), is generated by large and slower sources such as the acceleration of the slide mass, and turns and large bumps in the path of the debris flow (Kanamori and Given 1982; Dahlen 1993; Julian et al., 1998; Deparis et al., 2008). The short-period signals, higher than $1 \mathrm{~Hz}(<1 \mathrm{~s}$ period) are generated by smaller scale source processes such as chaotic flow within the debris flow and at the base of the debris flow as it flows over smaller features (Brodsky et al., 2003; Huang et al., 2007). The short period $(>1 \mathrm{~Hz})$ motions had an emergent onset, spindle-shaped signal, and low amplitudes in relation to their duration, typical of rock slides, debris avalanches and debris flows (Norris, 1994). The short period portion of the signal emerges about $25 \mathrm{~s}$ after the onset of the long period signal, but before the main long period impact signal, suggesting that disintegration of the mass began before the complete collapse of the secondary peak of Mount Meager onto the footslope.

Phases of landslide activity were inferred over the next $200 \mathrm{~s}$ based on analysis of seismic wave type, amplitude, and relative timing and corroborated by field observations. The pulses, their source description, and time from the signal onset are described in Table 2, with locations shown on Fig. 9. Identified pulses are nearly identical at other broadband stations, with some variation due to the radiation pattern, showing that these are source effects, not site effects or path effects.

The most well-defined of the long-period source events are $\mathrm{A}, \mathrm{B}$, and F. Event A is interpreted to be initial failures from the upper slopes onto the flanks below. The dominant period of these waves is about 17 to $20 \mathrm{~s}$, indicating a source process of about an equivalent length (Kanamori and Given 1982). This was confirmed by preliminary waveform modeling. Event B is higher in amplitude than Event A and is composed primarily of Rayleigh waves, suggesting a dominantly vertical force. This is interpreted as the collapse of the secondary peak onto the flanks below, mobilizing and disaggregating the material below into a high-velocity debris flow. The period of these Rayleigh waves was $10 \mathrm{~s}$, indicating a shorter source process than the initial failures (A), consistent with the expected signature of a collapse of the secondary peak of Mount Meager. These initial massive failures (A and B) are roughly equivalent to a single force source mechanism in the opposite direction of slide movement as a block accelerates, and in the same direction as slope movement as a block decelerates (Kanamori and Given, 1982; Dahlen, 1993; Julian et al., 1998). The polarization of the first arrivals of the Rayleigh waves and the variability in the amplitudes of both types of surface waves with azimuth indicate the correct radiation pattern for a single force. Preliminary waveform modeling supports the single force mechanism and suggests forces on the order of $10^{9} \mathrm{~N}$ for event $\mathrm{A}$ and $10^{9}-10^{10} \mathrm{~N}$ for event B.

Events $\mathrm{C}$ through $\mathrm{E}$ can roughly be correlated with turns in the path of the debris flow, a product of seismic waves generated by rotational accelerations. These events also occur when the short period energy is at its highest, suggesting that they coincide with peak debris flow velocities.

Event $\mathrm{F}$ is defined by a pulse nearly as high in amplitude as Event B, indicating another massive impact force. Site evidence showed that the debris flow burst out of Capricorn Creek valley into the facing wall of the Meager Creek valley, impacting a steep slope on the opposite side and running up 270 vertical meters before splitting up and down Meager Creek valley. This impact on the valley wall is the interpreted source for Event $F$.

Using these well-defined time markers and calculating path distance, we can make velocity estimates of the debris flow at various stages along the path. We calculate an average debris flow velocity of $67 \mathrm{~m} \mathrm{~s}^{-1}$. This is measured from the secondary peak failure (B) to the impact of the debris 


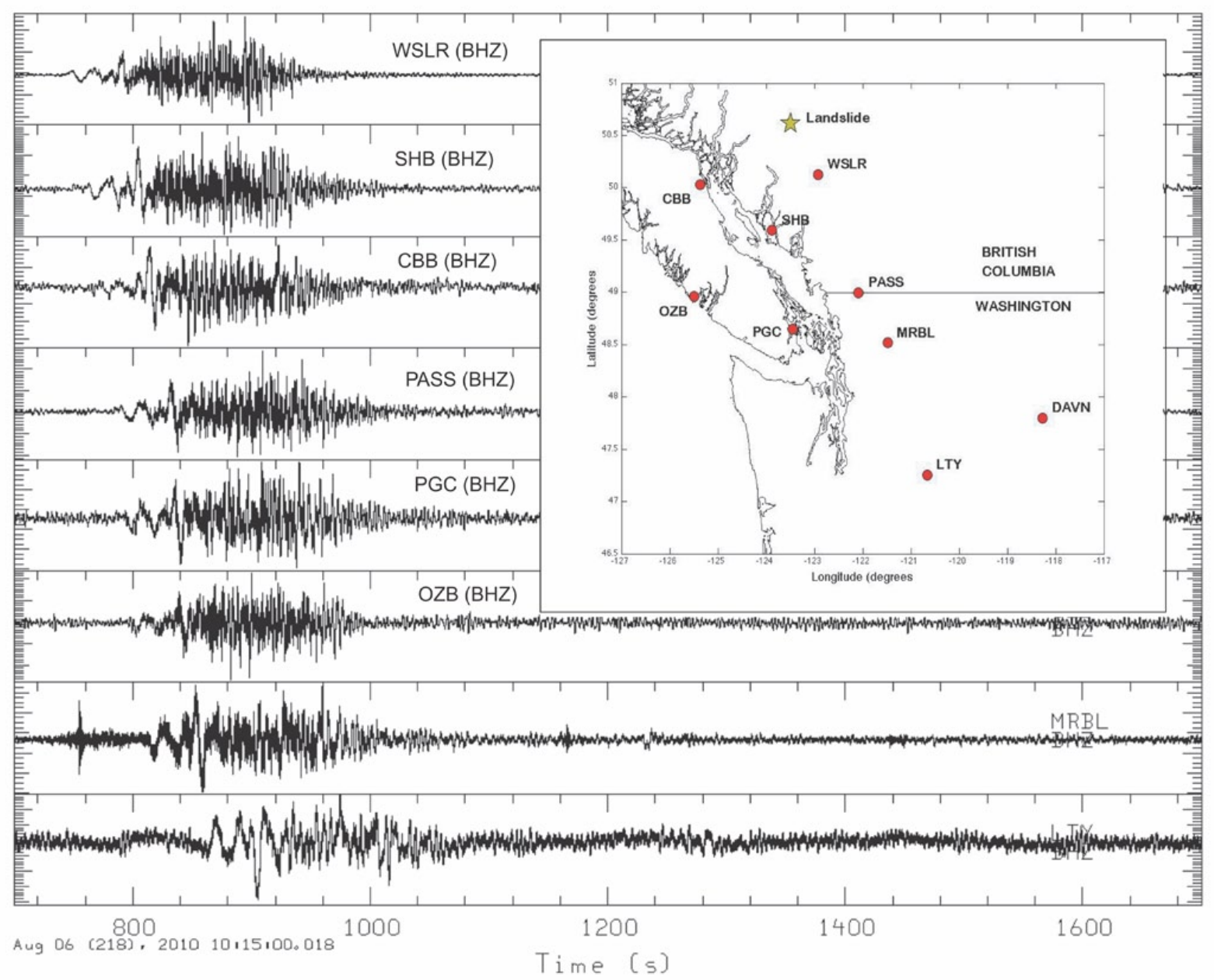

Fig. 7. Raw seismic signals from Mount Meager landslide recorded across southwestern Canada and northern Washington State (CNSN and PNSN data). Station and landslide location indicated on inset map.

flow at a right angle to Meager Creek $(\mathrm{F})$, covering a distance of about $7.3 \mathrm{~km}$ in $109 \mathrm{~s}$. Rough velocity estimates between each individual point are given on Table 2, including error margins on distance and timing. The error margins are due to uncertainties in defining points, selecting distances between points because these are not point sources, uncertainties in picking arrival times for these long period pulses, and differences in surface waves velocities at different periods. It is more difficult to accurately define the end of the debris flow, as the energy fades gradually on the seismic record.

A second long-period seismic pulse occurs about $7 \mathrm{~min}$ after the main collapse began. The waveform of Event $\mathrm{H}$ is similar to event A, but smaller in amplitude, and is interpreted as a subsequent smaller volume rock fall or rock slide from the now over-steepened face of Mount Meager, an "aftershock" of sorts. Field work over the next month revealed that smaller rock falls were frequent and ongoing from the source zone.
There were no precursory seismic events recorded prior to the main landslide. However, the seismic stations are $70 \mathrm{~km}$ away or farther, so small precursors might have escaped our observation.

\subsection{Simulation using DAN-W}

A first-order dynamic back analysis of the Mount Meager rock avalanche was completed using the two-dimensional numerical simulation model DAN-W (Hungr, 1995; Hungr and McDougall, 2009). DAN-W has been used to simulate the behavior (i.e. run-out distance, velocity along path, and deposition) of a number of catastrophic landslides including rock avalanches, debris avalanches, and debris flows (e.g. Hungr and Evans, 1996; Evans et al., 2001, 2007; Hungr and Evans, 2004; Sosio et al., 2008; among others).

A Voellmy rheology (Hungr, 1995) was selected to model the basal resistance of the moving mass. The Voellmy basal resistance model includes frictional $(f)$ and turbulence $(\xi)$ 


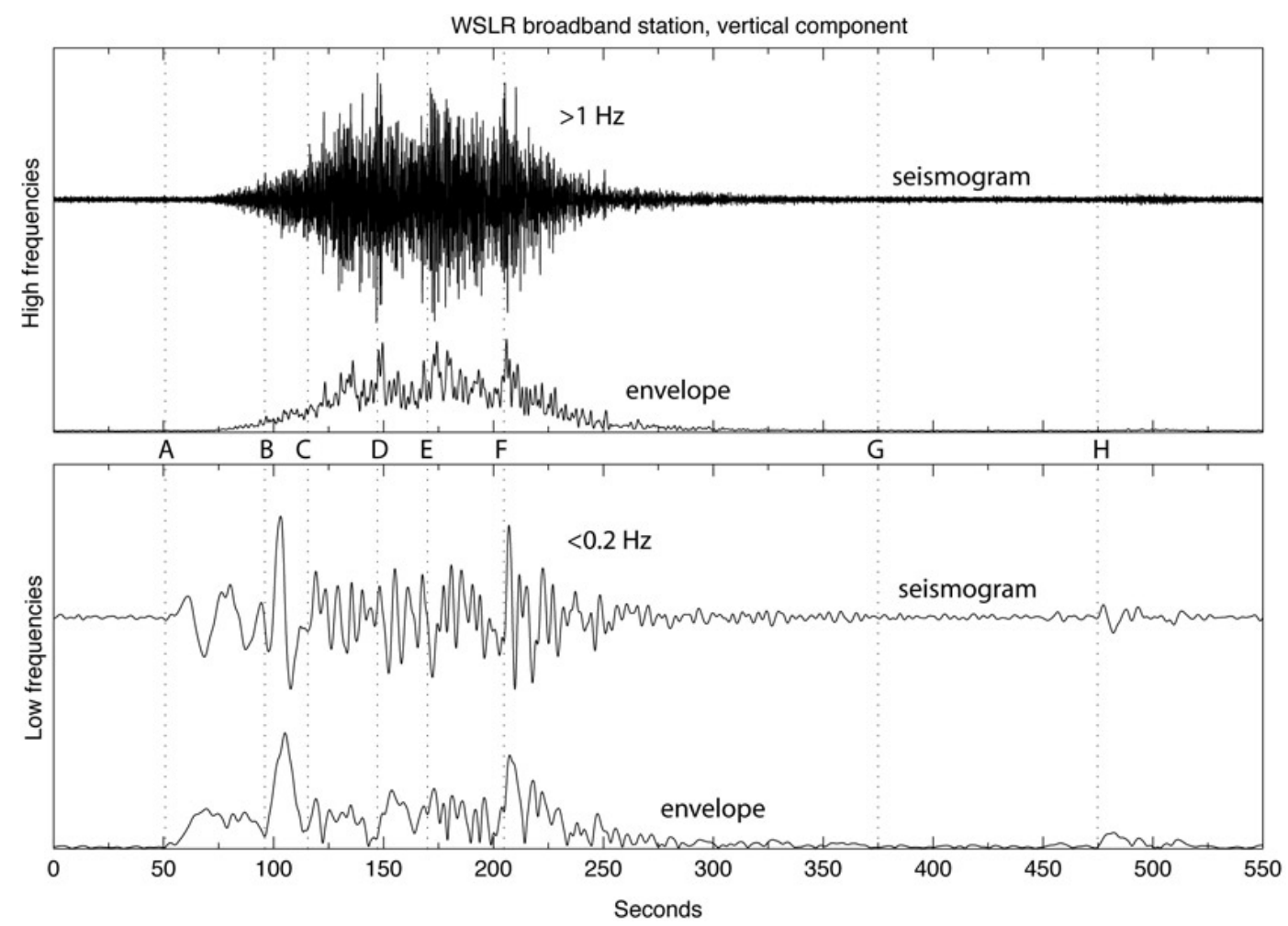

Fig. 8. WSLR broadband recording of the landslide single-pass highpass filtered ( $>1 \mathrm{~Hz}$ top) and lowpass filtered $(<0.2 \mathrm{~Hz}$, bottom) and plotted with envelopes. Dashed vertical lines are labeled with letters that correspond to Fig. 9 and discussion in text.

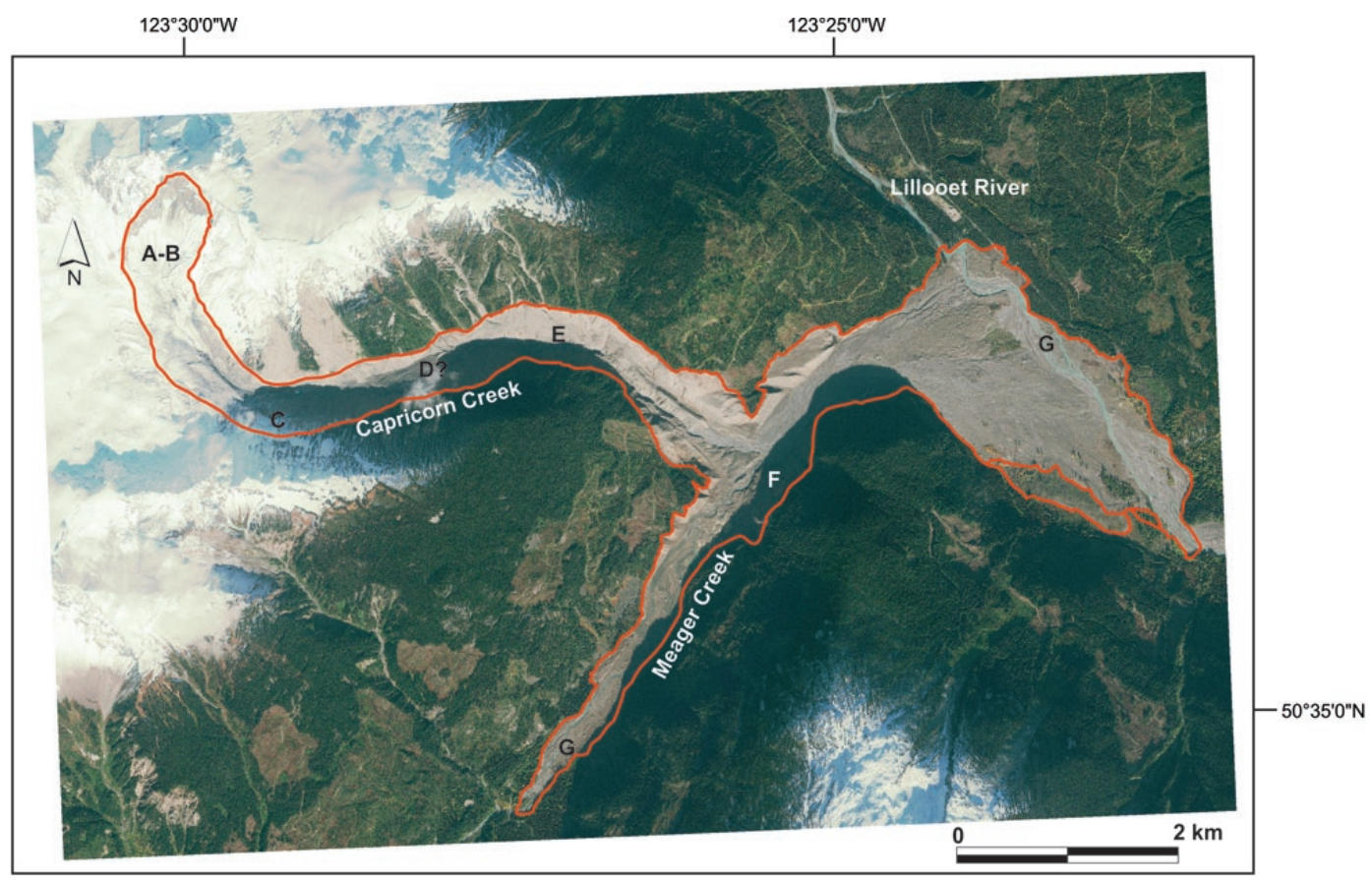

Fig. 9. The complete outline of the Mount Meager landslide showing the initiation zone (A-B), the two major bends (C and E), the facing wall of Meager Creek (F), and the bifurcated flow that travelled up Meager Creek, and across the Lillooet River (G). The image was taken following the breach of the Meager Creek dam, and fluvial reworking and considerable incision of the dam itself are evident. 
Table 2. Time markers along landslide path according to the seismic signature at stations in the Pacific Northwest (see Figs. 7-9 for path and station locations and seismic trace associated with each marker).

\begin{tabular}{|c|c|c|c|c|c|c|c|}
\hline $\begin{array}{l}\text { Source } \\
\text { event }\end{array}$ & Description & $\begin{array}{r}\text { Time from } \\
\text { slide onset } \\
(\mathrm{s})\end{array}$ & $\begin{array}{r}\text { Error } \\
(\mathrm{s})\end{array}$ & $\begin{array}{r}\text { Distance from } \\
\text { previous point } \\
(\mathrm{km})\end{array}$ & $\begin{array}{r}\text { Range of distances } \\
(\text { error margin) } \\
(\mathrm{km})\end{array}$ & $\begin{array}{r}\text { Average } \\
\text { velocity } \\
\left(\mathrm{m} \mathrm{s}^{-1}\right)\end{array}$ & $\begin{array}{r}\text { Velocity } \\
\text { range }^{1} \\
\left(\mathrm{~m} \mathrm{~s}^{-1}\right)\end{array}$ \\
\hline A & $\begin{array}{l}\text { Initial failures from high on } \\
\text { slopes }\end{array}$ & 0 & \pm 1 & - & - & - & - \\
\hline B & $\begin{array}{l}\text { Secondary peak collapses and } \\
\text { mobilizes flanks below into de- } \\
\text { bris flow }\end{array}$ & 45.3 & \pm 2 & 0 & - & - & - \\
\hline $\mathrm{C}$ & Debris flow turns first corner & 64.9 & \pm 2 & 1.7 & $1.5-2.5$ & 87 & $70-142$ \\
\hline $\mathrm{D}$ & $\begin{array}{l}\text { Debris flow flows over bump } \\
\text { and slight turn in path }\end{array}$ & 96.5 & \pm 4 & 1.7 & $1.7-3$ & 54 & $54-109$ \\
\hline $\mathrm{E}$ & $\begin{array}{l}\text { Debris flow turns last corner in } \\
\text { Capricorn Creek }\end{array}$ & 119.3 & \pm 5 & 1.4 & $0.8-1.9$ & 61 & $29-107$ \\
\hline $\mathrm{F}$ & $\begin{array}{l}\text { Front of debris flow strikes wall } \\
\text { across Meager Creek }\end{array}$ & 154.1 & \pm 0.5 & 2.2 & $1.8-2.5$ & 63 & $51-73$ \\
\hline G & $\begin{array}{l}\text { Seismic signal drops below } \\
\text { noise level, apparent end of de- } \\
\text { bris flow }\end{array}$ & 324.3 & \pm 10 & 3 & $3-3.5$ & 18 & $17-22$ \\
\hline $\mathrm{H}$ & $\begin{array}{l}\text { Second smaller rockslide re- } \\
\text { leased from Mount Meager }\end{array}$ & 424.1 & \pm 0.5 & - & - & - & - \\
\hline
\end{tabular}

${ }^{1}$ From previous event location to current event.

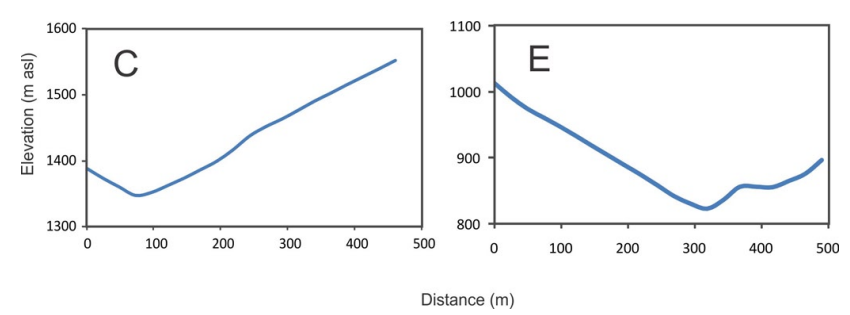

Fig. 10. Cross-sectional profiles from the upper bend $(\mathbf{C})$ and the lower bend (E) used for velocity calculations in Fig. 9.

parameters, which are estimated on the basis of field conditions to produce a simulation that best fits observed behaviour

$\tau_{z x}=\sigma_{z f}+p g v^{2} / \xi$

where $\tau_{z x}$ is the basal friction model, $\sigma_{z}$ is the bed normal stress at the base of the flow, $f$ is the frictional coefficient, $\rho$ is the material density, $g$ is the gravitational constant, $v$ is the averaged depth flow velocity, and $\xi$ is the turbulence term.

The reader is referred to Hungr $(1995,2008)$ for details about the input parameters. Output parameters include path velocity and time.

The BC TRIM DEM was used for pre-event surface topography and the GeoEye DEM was used to generate a postevent surface (see Sect. 3.2 for details). These two datasets defined the source region and initial volume $\left(48.5 \mathrm{Mm}^{3}\right)$ of the landslide.
Path width from the GeoEye image (Fig. 9) was entered directly into DAN-W along with topography and model parameters. Field evidence of post-failure behaviour indicated limited path-erosion and therefore entrainment was not considered in this simulation.

Four surface materials were defined for four segments along the path of the landslide. The values of friction and turbulence parameters for each of these segments that best simulated the landslide behavior are listed in Table 3. We note that the values of the Voellmy parameters for the surface materials in the four path segments fall within the range used in previous successful simulations of similar movements (e.g. Hungr and Evans, 1996; Ayotte and Hungr, 2000; Evans et al., 2009) and generally reflect the transformation of an initial fragmenting rockslide into a fast-moving flow.

Simulations of velocity verus distance and velocity versus time relationships were compared to estimation of velocity from superelevation of debris in the two major bends ( $\mathrm{C}$ and E on Fig. 10), run-up velocity at the Capricorn Creek - Meager Creek confluence, and velocity measured in the seismic analysis.

Superelevation velocities were measured using

$V_{\min }=g h r / w$

where $V_{\min }=$ the minimum velocity in $\mathrm{ms}^{-1}, g=$ the gravitational constant, $h=$ the run-up height, $r=$ is the radius of curvature in a bend, and $w=$ the width of the path. 
Table 3. Friction and turbulence parameters along path segments used in DAN-W.

\begin{tabular}{lrrrr}
\hline Segment & \multicolumn{2}{l}{ Path distance $(\mathrm{m})$} & Friction & Turbulance \\
\cline { 2 - 3 } & Start & End & $(f)$ & $(\xi)$ \\
\hline 1 & 0 & 1407 & 0.06 & 750 \\
2 & 1408 & 6452 & 0.1 & 900 \\
3 & 6453 & 7793 & 0.02 & 1250 \\
4 & 7792 & 12453 & 0.02 & 550 \\
\hline
\end{tabular}

Run-up velocity was also measured at the Capricorn Creek - Meager Creek confluence using

$V_{\min }=(2 g h)^{0.5}$

where $V_{\min }=$ the minimum velocity in $\mathrm{m} \mathrm{s}^{-1}, g=$ the gravitational constant, and $h=$ the run-up height.

Results of the superelevation analysis indicate minimum flow velocities of $62 \mathrm{~m} \mathrm{~s}^{-1}$ in bend 1 and $73 \mathrm{~m} \mathrm{~s}^{-1}$ in bend 2 . These compare to $84.3 \mathrm{~m} \mathrm{~s}^{-1}$ and $81.2 \mathrm{~m} \mathrm{~s}^{-1}$ for the respective bends in the DAN-W simulation, and $87 \mathrm{~m} \mathrm{~s}^{-1}$ and $61 \mathrm{~m} \mathrm{~s}^{-1}$, respectively, on the seismic trace. The simulated velocities are higher than the velocities calculated from the profile alone, but match the seismic trace quite closely for the first bend. It is likely that a bedrock wall at the beginning of bend 1 limited the superelevation, making the profile velocity sensitive to where in the curve the measurement was taken. We had difficulty matching DAN-W simulated velocity values with the inferred field velocities based on debris behavior, whilst at the same time matching the path geometry requirement of run-out to the Lillooet River. Velocities approximating field estimates in bends in Capricorn Creek did not produce the observed long run out and higher-thanfield-estimate velocities were necessary to achieve approximate run-out distance in the simulation. Figures 11 and 12 show the results of the DAN-W analysis.

The geometry of the run-up at the confluence of Capricorn and Meager creeks suggests a minimum velocity of $63 \mathrm{~m} \mathrm{~s}^{-1}$ compared to a DAN-W simulated estimate of $53.3 \mathrm{~m} \mathrm{~s}^{-1}$ (Fig. 11).

Overall, the simulation gave a mean velocity to the confluence of Capricorn and Meager creeks of $68.4 \mathrm{~m} \mathrm{~s}^{-1}$ and a peak velocity of $91.2 \mathrm{~m} \mathrm{~s}^{-1}$. This compares favorably to the mean velocity of $67 \mathrm{~m} \mathrm{~s}^{-1}$ derived from the seismic traces.

Velocities following impact with the facing wall of Meager Creek were reduced as the debris bifucated and decelerated to the landslide's distal limit at Lillooet River. DAN-W indicates a mean velocity of $9.5 \mathrm{~m} \mathrm{~s}^{-1}$ between the landslide dam and the distal limit. We propose that this comparatively low velocity results from sudden deceleration following (1) the impact with the south side of Meager Creek at the CapricornMeager confluence, and (2) the sudden increase in the width of the path as the debris spread out over the Meager Creek

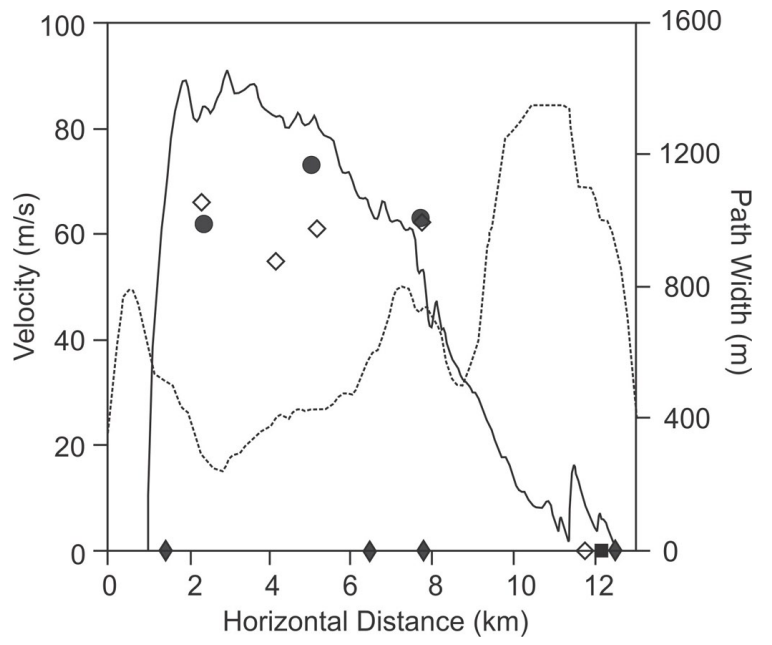

Fig. 11. The plot of frontal velocity versus path distance (solid line) and path width versus path distance (dashed line) for the 2010 Mount Meager landslide. Velocities are compared to estimates from superelevation and run-up data (black dots) and seismic analysis (open diamonds). The black square is actual field run-out and filled black diamonds denote the segments corresponding to the four materials in Table 3 .

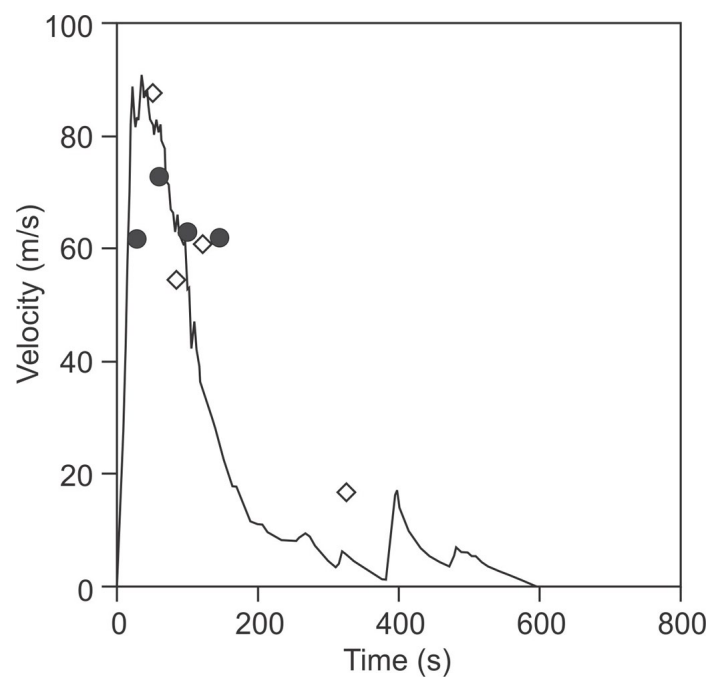

Fig. 12. DAN-W simulation plot of velocity versus time. Velocities are compared to estimates from superelevation in bends and run-up geometry (black dots) and seismic analysis (diamonds).

fan into the Lillooet River valley. The sudden deceleration is evident in Figs. 11 and 12.

With reference to velocity versus time relationships, there is broad correspondence between the results of DAN-W and the seismic trace for the initial part of the path up to the run-up at the confluence of Capricorn and Meager creeks. We note, however, that in Fig. 12, a large discrepancy is evident in run-out times between the seismic $(324 \mathrm{~s})$ and DAN-W analyses (621 s). This may be explained by the low 


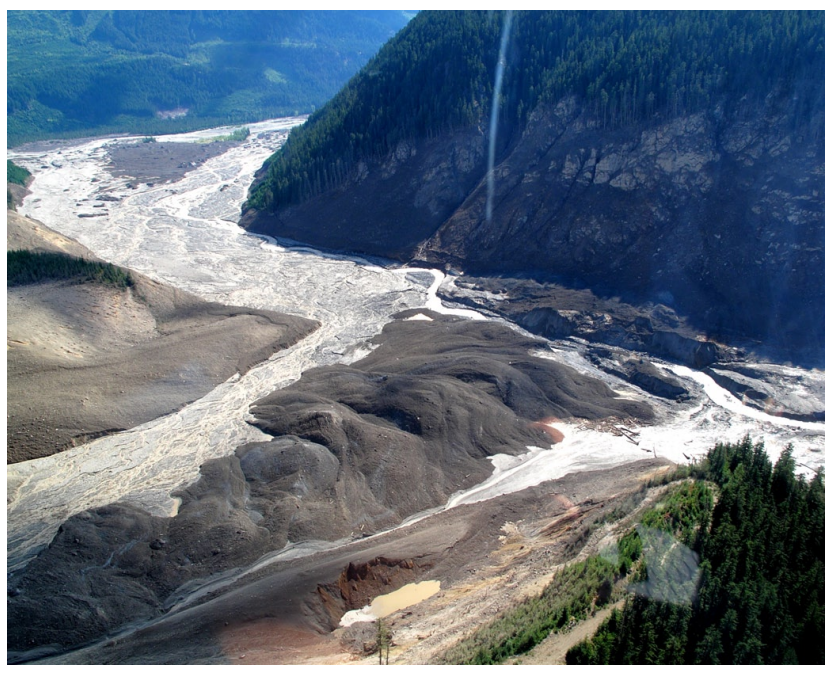

Fig. 13. The Meager Creek barrier after the dam outburst flood at the confluence of Capricorn and Meager creeks.

sensitivity threshold of the seismic recordings. We hypothesise that once the moving mass slowed to below $10 \mathrm{~m} \mathrm{~s}^{-1}$, it was no longer detectable by the seismographs above background seismic noise. The DAN-W analysis however, continues the movement until the velocities reach $0 \mathrm{~m} \mathrm{~s}^{-1}$, significantly extending the overall run-out time.

\subsection{Deposit morphology}

Capricorn Creek was predominantly V-shaped prior to the landslide in 2010. Following the 2010 event, the V-shaped valley floor was modified to form a flat-bottomed narrow trapezoid as material was deposited along the path. Deposition began immediately below the initiation zone of the Mount Meager landslide, in-filling the valley bottom and draping the valley sidewalls otherwise stripped bare of vegetation during the event (Fig. 6a-e). Debris incision along the valley floor occurred in later stages of the event, eroded by a liquid slurry as the debris flow reduced in size (inside the white dotted lines of Fig. 6a and c).

At the confluence of Capricorn and Meager creeks, the landslide encountered the opposing rock wall of the Meager Creek valley causing a vertical run up of $270 \mathrm{~m}$ and leaving a roughly triangular landslide dam (the Meager Creek barrier) approximately $700 \mathrm{~m} \times 500 \mathrm{~m}$ at the base, with a thickness of 30-50 m (Figs. 13 and 14). The landslide dam completely blocked Meager Creek for 19 hours, causing the formation of a landslide dam lake, and ultimately failing into the Lillooet River valley.

The path of the landslide along Meager Creek and Lillooet River was divided into six zones, each with a distinct geomorphic expression (Figs. 14 and 15): (1) spray zone; (2) trim zone; (3) Meager Creek deposit upstream of Capricorn Creek (upstream flow); (4) Meager Creek barrier deposit; (5) the downstream flow in Lillooet River valley including; (6) a thick deposition plug; and (7) late-stage debris flow zone forming the south edge of the deposit (after flow sector).

The spray zone consists of wind-thrown trees and thin deposition of debris ejected laterally as the debris front burst from the confining source valley into Meager Creek valley. The spray zone is about $500-600 \mathrm{~m}$ long on both sides of Capricorn Creek mouth on the north wall of Meager Creek valley.

The trim zone lies between the thick debris deposit and the forest edge. Here, in the area eroded by the passing of the frontal lobe, the pre-landslide surface was scoured of vegetation and covered with debris, thin on the side slopes, and thick in the valley bottom where the old V-shaped gulley was in-filled.

The deposit in Meager Creek upstream of the mouth of Capricorn Creek (the upstream flow) consists mainly of mixed sediment and debris filling an incised channel 5-15 m deep, 100-200 $\mathrm{m}$ wide, and extending $3250 \mathrm{~m}$ upstream from the Meager Creek barrier.

The barrier consists of compressed ridges formed of mixed debris and large grey blocks; the debris directly below the south valley wall, however, is hummocky rather than ridged, having run up the slope and and fallen back. The Meager Creek barrier was substantially altered by ongoing debris flows incising the deep valley floor deposits and the edge of the barrier, and then ultimately by the dam outburst flood described below.

The main deposit downstream along Meager Creek and Lillooet River was largely eroded by the outburst flood; its initial morphology was reconstructed from field observations and oblique air photographs from 6 August 2010. The landslide partially blocked the Lillooet River, causing a 10-15 m rise in water levels on the upstream side that destroyed a bridge at the landslide margin. As it spread across the Lillooet River valley, the flow was divided and slowed by an elevated rise in the valley floor from previous landslide deposits. The former deposits were overwhelmed by debris from 2010 event, and were buried under a deep plug of debris. The flow crossed Lillooet River valley, narrowly missed a forest recreation campsite on the other side and isolated campers who required rescue.

The debris flow spread across the Lillooet River valley, leaving behind abundant ponded surface water, hummocks, blocks, and compression ridges. Ongoing debris flows subsequent to the main event in-filled the south side of the valley, and reworking of the deposit began almost immediately following the landslide dam failure.

The morphology and architecture of the deposit is typical of large volcanic landslides, with hummocky topography, longitudinal flow banding and areas of transverse compression ridges (Siebert, 1984; Glicken, 1991; Dufresne and Davies, 2009). The low relief areas are underlain by matrixsupported, poorly-sorted debris with grain sizes ranging from 


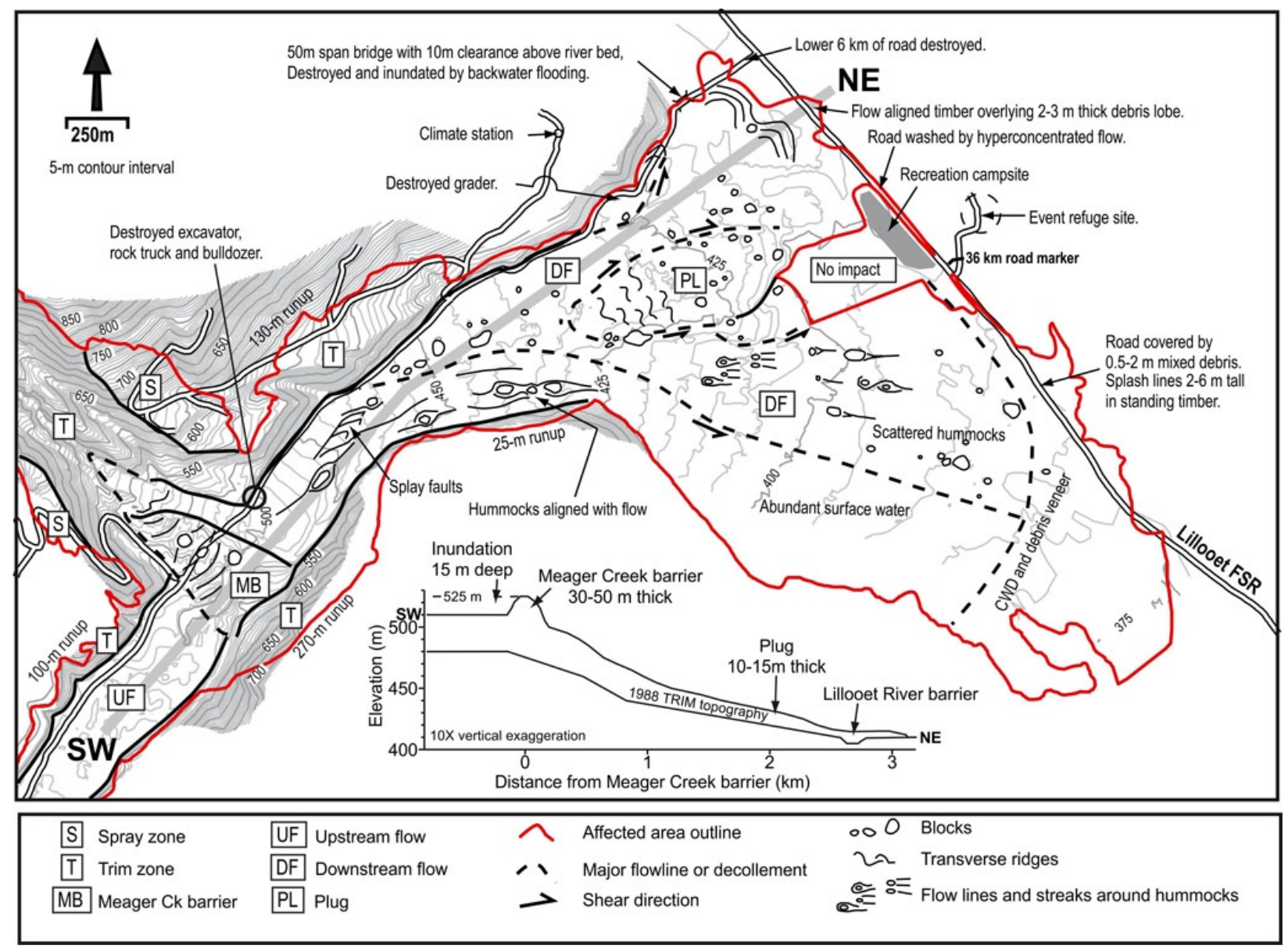

Fig. 14. Map of the landslide deposit in the valleys of lowermost Meager Creek and Lillooet River (see text for description).

clay to boulder-size. Individual hummocks stand up to several meters above the landslide surface, and are cored by blocks of the original rock mass.

\subsection{Failure of the Meager Creek landslide dam and outburst flood}

The landslide completely blocked Meager Creek and partially blocked the Lillooet River at its confluence with Meager Creek. The interruption in the flow of both rivers was recorded at Water Survey of Canada (WSC) hydrometric station 08MG005, located on Lillooet River, upstream of Pemberton, $61.3 \mathrm{~km}$ downstream from the confluence of the two rivers. The WSC gauge recorded the hydrometric response of both dams, and provides a unique opportunity to analyze the impacts of the landslide on the river system. Figure 16 shows the Lillooet River hydrograph for 6-7 August 2010.

The flow of Meager Creek was determined by comparing the flow at the Lillooet River WSC station following the event, to the estimated contribution of Meager Creek by watershed area. Meager Creek flow was thereby estimated at $36-38 \mathrm{~m}^{3} \mathrm{~s}^{-1}$. The landslide dam impounded between 2.6 and $2.7 \times 10^{6} \mathrm{~m}^{3}$ of new water over the next $20 \mathrm{~h}$ (Roche et al., 2011).

By $20: 30 \mathrm{~h}$ on 6 August, it was clear that overtopping of the dam was imminent and approximatley 1500 residents in the lower Lillooet Valley were asked to evacuate.

We estimate a total floodwave volume of $2.9 \times 10^{6} \mathrm{~m}^{3}$ following overtopping of the Meager Creek barrier. This amount includes introduced water (stored in the dam or in sediments along the path) and sediment content in the volume calculation.

The lake overtopped the landslide dam at around 23:30 h on 6 August and reached a peak discharge of several hundred $\mathrm{m}^{3} \mathrm{~s}^{-1}$ at about 01:00 h on 7 August. The floodwave travelled downstream toward Pemberton with an average velocity of approximately $2.5 \mathrm{~m} \mathrm{~s}^{-1}$. The peak passed the Hurley River Forest Service Road bridge (38 km downstream) at about 04:30 h and the Water Survey of Canada gauge $(61 \mathrm{~km}$ downstream) at $07: 45 \mathrm{~h}$. Flows attenuated in velocity and volume with distance; however, high flows persisted and discharge at Pemberton, almost $7 \mathrm{~h}$ after the peak remained about $200 \mathrm{~m}^{3} \mathrm{~s}^{-1}$ above the pre-wave condition. 


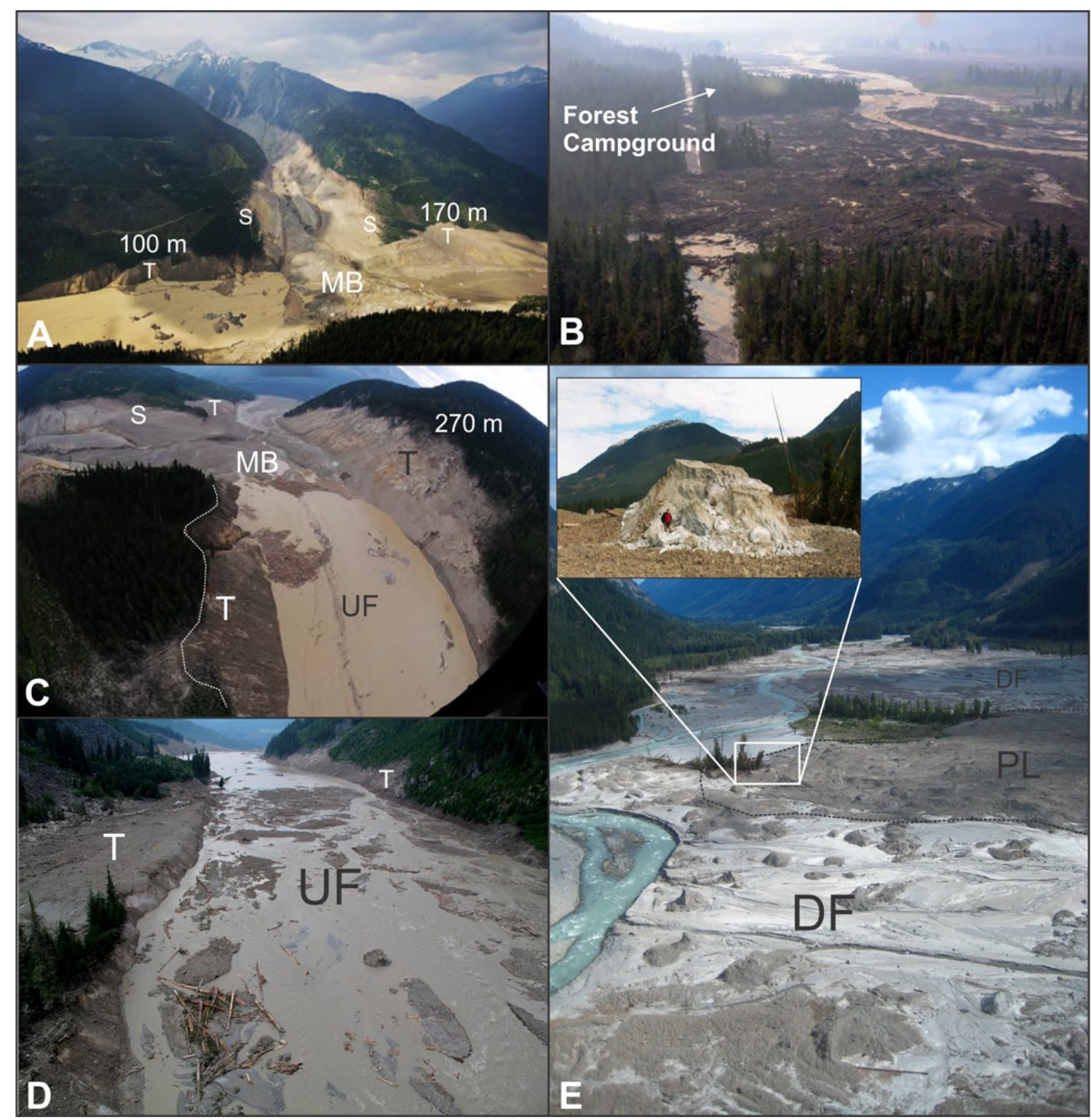

Fig. 15. Deposition features in lower Meager Creek. $P L=$ plug; $D F=$ downstream flow; $U F=$ upstream flow; $T=$ trim zone; $S=s p r a y$ zone. Image (A) is at the Capricorn-Meager confluence (photo by B. Makarewicz); (B) shows the downstream flow against the east wall of the Lillooet River valley; (C) and (D) are upstream of the Meager Barrier (photo C by D. B. Steers); and (E) is the downstream flow and plug.

\subsection{Socio-economic and environmental impacts}

Despite the remote location of the 2010 Mount Meager landslide, the event had considerable socio-economic impact. Approximately $110000 \mathrm{~m}^{3}$ of wood was stripped away from the slopes of Capricorn Creek and Meager Creek and the Lillooet River valley bottom and either pulverized into fine organic material, or transported as large woody debris into the river system. The wood was a mixture of western hemlock, amabilis and subalpine fir, western red cedar, and to a lesser extent lodgepole pine and balsam poplar. Wood species and volume were obtained from recent forest cover maps, and multiplied by the average log market value for August 2010 (Province of British Columbia, 2011). The total potential loss based on the markets at the time of the event was $\$ 8.7$ M CAD. In addition, two forest service bridges and road construction equipment were destroyed, along with several kilometers of roads including almost $6 \mathrm{~km}$ of the Meager Creek forest service road.

The landslide and the subsequent threat of a dam outburst flood on Meager Creek caused the evacuation of approximately 1500 residents in the lower Lillooet River valley for one night, and rescue efforts for several campers and workers in the vicinity of Mount Meager. 


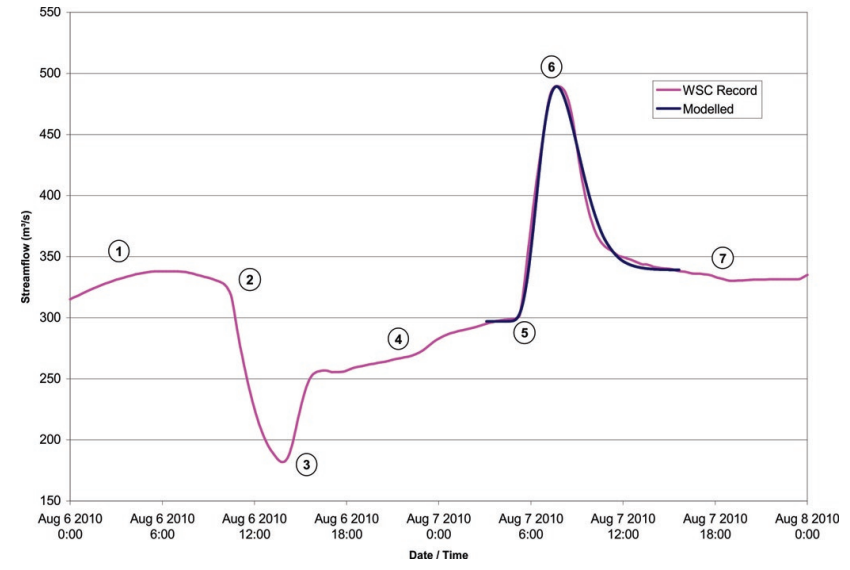

Fig. 16. WSC gauge 08MG005, Lillooet River near Pemberton. The gauge records the response of the Lillooet River at Pemberton to the Mount Meager landslide and subsequent damming events. Delay time to the station is approximately $6 \mathrm{~h}$ and $45 \mathrm{~min}$. 1, stable base flow (curve is diurnal fluxuation in stream flow); 2 , initial drop in flow due to the complete blockage of Meager Creek, and partial blockage of Lillooet at 10:15; flow dropped to $182 \mathrm{~m}^{3} \mathrm{~s}^{-1}$; 3 , rapid recovery of flow beginning at 13:15 associated with the incision of Lillooet River through the landslide deposit; 4, continued gradual recovery of Lillooet River flow, minus the Meager Creek portion; 5 , arrival of the Meager dam breach floodwave at 05:15; 6, arrival of the flood peak at $07: 45 ; 7$, re-establishment of stream flow conditions. The blue line represents the modelled dam breach and corroborates the observed stage discharge at Pemberton.

Sediment moving downstream puts pressure on the Pemberton district dyking system, raising the effective flood levels, and the obliteration of Capricorn Creek and inundation of Meager Creek will have long-lasting environmental effects.

In total, direct costs associated with the event are estimated at \$10 MCAD. If gravel removal or dike elevation changes become necessary as a result of the increased sediment load, the total long-term costs of this landslide could exceed the direct costs.

\subsection{Eyewitness account}

Eyewitness accounts, while arguably less scientific, provide important corroboration and context to rarely seen catastrophic events. In the case of the Mount Meager landslide, no lives were lost; however, four witnesses to the event were in extreme jeopardy on several occasions during and immediately following the landslide. K. Kraliz, J. Duffy, J. Tilley, and P. Smith, along with their dog, arrived at upper Lillooet forest campsite at 3:25 a.m. and began unloading their gear. They were surprised by "two large cracks" (loud explosive noises, not physical cracks in the ground) occurring in quick succession, followed by a rumbling that initially sounded like a train or a forest fire, but that grew to a deafening volume in about $20 \mathrm{~s}$ (P. Smith, personal communication, 2010). All four campers and their dog got back into their truck and headed for higher ground. Chaos ensued for the next few hours before daylight as they encountered debris flows, mud, falling trees and other hazards at the edge of the landslide deposit in the Lillooet River valley. The most alarming part of their story occurred as they came face to face with a 1.5$\mathrm{m}$ high wall of mud and water that appeared to them like a "turbulent bubbling wedge of black oil" (P. Smith, personal communication, 2010). They turned their truck around, but not before they were overtaken by the hyper-concentrated flow. Accelerating rapidly, they nonetheless escaped, in what P. Smith described as most resembling "the Millennium Falcon escaping the Death Star explosion at the end of Return of the Jedi" (personal communication, 2010).

The account corroborates both the approximate time of the event, the violent nature and noise level of a massive landslide even at the distal margins, and ongoing activity on the landslide long after the main event occurred. We propose that the two cracks (loud explosive noises) are the subjective memory of the impact of the failing secondary peak.

\section{Conclusions}

In this paper we have documented a large catastrophic landslide that occurred in August 2010 on the southern flank of Mount Meager, a dissected Quaternary volcanic centre within the Mount Meager Volcanic Complex (MMVC) of southwestern British Columbia. The initial failure mass had a volume of $48.5 \times 10^{6} \mathrm{~m}^{3}$ and involved a slope consisting of poor quality volcanic rock. The failed rock mass rapidly transformed into a high-velocity debris flow that swept $7.8 \mathrm{~km}$ down Capricorn Creek to dam Meager Creek. At Meager Creek, the debris flow split and traveled $3.7 \mathrm{~km}$ upstream, and $4.9 \mathrm{~km}$ downstream across the Lillooet River, creating landslide dams on both streams. Our analysis of superelevation in the bends of Capricorn Creek and the dramatic run-up at the confluence of Capricorn Creek and Meager Creek suggest average velocities of $62-73 \mathrm{~m} \mathrm{~s}^{-1}$ and $63 \mathrm{~m} \mathrm{~s}^{-1}$, respectively.

The 2010 Mount Meager landslide is significant for seven reasons; (1) it is the tenth mass flow involving volumes in excess of $0.5 \times 10^{6} \mathrm{~m}^{3}$ to have occurred in the MMVC since 1850 and the sixth largest mass flow identified in the MMVC over the Holocene; (2) it is one of the largest landslides to have occurred worldwide since 1945; (3) the landslide exhibited dramatic transformation from an initial rock slope failure to a rapidly moving debris flow as a result of the high degree of fragmentation of the initial failure mass; (4) the formation of a significant landslide dam illustrated the importance of landslide damming as a secondary landslide process and as a hazard to distant downstream communities; (5) the seismic trace of the landslide initiation and motion allowed detailed reconstruction of the stages and velocity of movement; (6) the event demonstrates the role of rapid post-Little Ice Age deglaciation in destabilising slopes adjacent to modern 
glaciers; and (7) it represents a unique opportunity to consider hazard and risk from catastrophic failures to mountain communities.

The event illustrates the extreme landslide hazard of glacier-clad dissected Quaternary volcanic centres, which results from the existence of steep slopes in poor quality rock (reflecting such factors as hydrothermal alteration and heterogeneity of volcanic products). In this geological environment, landslides are a major process of denudation and, through transformation into debris flows, deliver large volumes of debris to river systems.

Acknowledgements. The authors gratefully acknowledge logistical support provided by the province of British Columbia, the Centre for Natural Hazard Research at the Simon Fraser University, and the Landslide Research Programme at the University of Waterloo.

Edited by: D. Keefer

Reviewed by: E. Harp and another anonymous referee

\section{References}

Ayotte, D. and Hungr, O.: Calibration of a runout prediction model for debris flows and avalanches, in: Proceedings of the 2nd International Conference on Debris Flows, Taipei, edited by: Wieczorek, G. F. and Naeser, N. D., Balkema, Rotterdam, 505-514, 2000.

Berrocal, J., Espinosa, A. F., and Galdos, J.: Seismological and geological aspects of the Mantaro landslide in Peru, Nature, 275, 532-536, 1978.

Bovis, M. J. and Jakob, M.: The July 29, 1998, debris flow and landslide dam at Capricorn Creek, Mount Meager Volcanic Complex, southern Coast Mountains, British Columbia, Can. J. Earth Sci., 37, 1321-1334, 2000.

Brodsky, E. E, Gordeev, E., and Kanamori, H.: Landslide basal friction as measured by seismic waves, Geophys. Res. Lett., 30, 2236 I-1-2236 I-5, 2003.

Carter, N. M.: Exploration in the Lillooet River watershed, Can. Alpine J., 21, 8-18, 1932.

Clague, J. J.: Late Quaternary Geology and Geochronology of British Columbia Part 2: Summary and Discussion of Radiocarbon-dated Quaternary History, Geol. Surv. Can. Pap., 80-35, 41 pp., 1981.

Clague, J. J., Evans, S. G., Rampton, V. N., and Woodsworth, G. J.: Improved age estimates for the White River and Bridge River tephras, western Canada, Can. J. Earth Sci., 32, 1172-1179, 1995.

Croft, S. A. S.: Stability Assessment of the Capricorn Creek Valley, British Columbia, B.Sc. thesis, University of British Columbia, Vancouver, BC, 1983.

Dahlen, F. H.: Single-force representation of shallow landslide sources, Bull. Seismol. Soc. Am., 83, 130-143, 1993.

Decker, F., Fougberg, M., and Ronayne, M.: Pemberton: The History of a Settlement, Hemlock Printing Ltd., Burnaby, BC, 1977.

Deparis, J., Jongmans, D., Cotton, F., Baillet, L., Thouvenot, F., and Hantz, D.: Analysis of rock-fall and rock-fall avalanche seismograms in the French Alps, Bull. Seismol. Soc. Am., 98, 17811796, 2008.
Dufresne, A. and Davies, T. R.: Longitudinal ridges in mass movement deposits, Geomorphology, 105, 171-181, 2009.

Evans, S. G.: A rock avalanche from the peak of Mount Meager, British Columbia, Geol. Surv. Can. Pap. 87-1A, 929-934, 1987.

Evans, S. G.: Landslides, in: A synthesis of Geological Hazards in Canada, Geol. Surv. Can. Bull., 548, 43-80, 2001.

Evans, S. G.: Single event landslides resulting from massive rock slope failure: Characterising their frequency and impact on society, in: Landslides from Massive Rock Slope Failure, edited by: Evans, S. G., Scarascia-Mugnozza, G., Strom, A. L., and Hermanns, R. L., NATO Sci. Ser. IV, Earth Environ. Sci., Springer, Dordrecht, 49, 53-73, 2006.

Evans, S. G., Hungr, O., and Clague, J. J.: Dynamics of the 1984 rock avalanche and associated debris flow on Mount Cayley, British Columbia, Canada; Implications for landslide hazard assessment on dissected volcanoes, Eng. Geol., 61, 29-51, 2001.

Evans, S. G., Guthrie, R. H., Roberts, N. J., and Bishop, N. F.: The disastrous 17 February 2006 rockslide-debris avalanche on Leyte Island, Philippines: a catastrophic landslide in tropical mountain terrain, Nat. Hazards Earth Syst. Sci., 7, 89-101, doi:10.5194/nhess-7-89-2007, 2007.

Evans, S. G., Roberts, N. J., Ischuck, A., Delaney, K. B., Morozova, G. S., and Tutubalina, O.: Landslides triggered by the 1949 Khait earthquake, Tajikistan, and associated loss of life, Eng. Geol., 109, 195-212, 2009.

Friele, P. and Clague, J. J.: Large Holocene landsldies from Pylon Peak, southwestern British Columbia, Can. J. Earth Sci., 41, 165-182, 2004.

Friele, P. and Clague, J.J.: Paraglacial geomorphology of Quaternary volcanic landscapes in the southern Coast Mountains, British Columbia, in: Periglacial and Paraglacial Processes and Environments, edited by: Knight, J. and Harrison, S., Geol. Soc. Spec. Publ. London, 320, 219-233, 2009.

Friele, P., Clague, J. J., Simpson, K., and Stasiuk, M.: Impact of a Quaternary volcano on Holocene sedimentation in the Lillooet River valley, British Columbia, Sediment. Geol., 176, 305-322, 2005.

Friele, P., Jakob, M., and Clague, J. J.: Hazard and risk from large landslides from Mount Meager volcano, British Columbia, Canada, Georisk, 2, 48-64, 2008.

Glicken, H.: Sedimentary architecture of large volcanic-debris avalanches, in: Sedimentation in volcanic settings, edited by: Smith, G. A. and Fisher, R. V., SEPM, Tulsa, Special Publication, 45, 99-106, 1991.

Guthrie, R. H. and Evans, S. G.: Work, persistence and formative events: The geomorphic impact of landslides, Geomorphology, 88, 266-275, 2007.

Hickson, C. J.: Character of volcanism, volcanic hazards, and risk, northern end of the Cascade magmatic arc, British Colubmia and Washington State, in: Geology and Geological Hazards of the Vancouver Region, Southwestern British Columbia, edited by: Monger, J. W. H., Geol. Surv. Can. Bull., 481, 231-250, 1994.

Holm, K., Bovis, M., and Jakob, M.: The landslide response of alpine basins to post-Little Ice Age glacial thinning and retreat in southwestern British Columbia, Geomorphology, 57, 201-216, 2004.

Huang, C.-J., Yin, H.-Y, Chen, C.-Y., Yeh, C.-H., and Wang, C.-L.: Ground vibrations produced by rock motions and debris flows, J. Geophys. Res., 112, F02014, doi:10.1029/2005JF000437, 2007. 
Hungr, O.: A model for the runout analysis of rapid flow slides, debris flows, and avalanches, Can. Geotech. J., 32, 610-623, 1995.

Hungr, O.: Simplified models of spreading flow of dry granular material, Can. Geotech. J., 45, 1156-1168, 2008.

Hungr, O. and Evans, S. G.: Rock avalanche runout prediction using a dynamic model, in: Proceedings of the 7th International Symposium on Landslides, Trondheim, Norway, 1, 233-238, 1996.

Hungr, O. and Evans, S. G.: Entrainment of debris in rock avalanches: An analysis of a long run-out mechanism, Geol. Soc. Am. Bull., 116, 1240-1252, 2004.

Hungr, O. and McDougall, S.: Two numerical models for landslide dynamic analysis, Comp. Geosci., 35, 978-992, 2009.

Jakob, M.: Morphometric and Geotechnical Controls on Debris Flow Frequency and Magnitude in Southwestern British Columbia. Ph.D. thesis, University of British Columbia, Vancouver, BC, 1996.

Jordan, P.: Debris Flows in the Southern Coast Mountains, British Columbia: Dynamic behaviour and physical properties, Ph.D. thesis, University of British Columbia, Vancouver, BC, 1994.

Julian, B. R., Miller, A. D., and Foulger, G. R.: Non-double-couple Eearthquakes, 1. Theory, Rev. Geophys., 36, 525-549, 1998.

Kanamori, H. and Given, J. W.: Analysis of long-period seismic waves excited by the May 18, 1980 eruption of Mount St. Helens - A terrestrial monopole?, J. Geophys. Res., 87, 5422-5432, 1982.

Lipovsky, P. S., Evans, S. G., Clague, J. J., Hopkinson, C., Couture, R., Bobrowsky, P., Ekström, G., Demuth, M. N., Delaney, K. B., Roberts, N. J., Clarke, G., and Schaeffer, A.: The July 2007 rock and ice avalanches at Mount Steele, St. Elias Mountains, Yukon, Canada, Landslides, 5, 445-455, doi:10.1007/s10346-008-01334, 2008.

Mathews, W. H. and McTaggart, K. C.: Hope rockslides, British Columbia Canada, in: Rockslides and Avalanches, Natural Phenomona, edited by: Voight, B., Elsevier, New York, 259-275, 1978.

McNeely, R. and McCuaig, S.: Geological Survey of Canada Radiocarbon Dates XXIX, Geol. Surv. Can. Pap. 89-9, 1991.

McSaveney, M. J. and Downes, G.: Application of landslide seismology to some New Zealand rock avalanches, in: Landslides, edited by: Rybar, J., Stemberk, J., and Wagner, P., Balkema, Lisse, 649-654, 2002.

Mokievsky-Zubok, O.: Glacier caused slide near Pylon Peak, British Columbia, Can. J. Earth Sci., 15, 1039-1052, 1977.
Nasmith, H., Mathews, W. H., and Rouse, G. E.: Bridge River ash and some other Recent ash beds in British Columbia, Can. J. Earth Sci., 4, 163-170, 1967.

Norris, R. D.: Seismicity of rockfalls and avalanches at three Cascade Range volcanoes: Implications for seismic detection of hazardous mass movements, Bull. Seismol. Soc. Am., 84, 19251939, 1994.

Province of British Columbia: Coast selling price system, average $\log$ prices for the 1 month period ending 2010-08-31, Province of British Columbia, Ministry of Forests, Mines and Lands online resource, available at: http://www.for.gov.bc.ca/hva/logreports_ coast.htm, last access: 4 March 2011.

Read, P. B.: Geology, Meager Creek Geothermal Area, British Columbia, Geol. Surv. Can. Open File 603, 1978.

Read, P. B.: Mount Meager complex, Garibaldi Belt, southwestern British Columbia, Geosci. Can., 17, 167-170, 1990.

Roche, A. D., Guthrie, R. H., Roberts, N. J., Ellis, E., and Friele, P.: Once more into the breach: A forensic analysis of the August 2010 landslide dam outburst flood at Meager Creek, British Columbia, in: Proceedings of the 5th Canadian Conference on Geotechnique and Natural Hazards, Canadian Geotechnical Society, May 15-17, 2011, Kelowna, BC, 10 pp., 2011.

Siebert, L.: Large volcanic debris avalanches: Characteristics of source areas, deposits and associated eruptions, J. Volc. Geo. Res., 22, 163-197, 1984.

Simpson, K. A., Stasiuk, M., Shimamura, K., Clague, J. J., and Friele, P. A.: Evidence for catastrophic volcanic debris flows in Pemberton Valley, British Columbia, Can. J. Earth Sci., 43, 679689, 2006.

Sosio, R., Crosta, G. B., and Hungr, O.: Complete dynamic modeling calibration for the Thurwieser rock avalanche (Italian Central Alps), Eng. Geol., 100, 11-26, 2008.

Stasiuk, M. V., Russell, J. K., and Hickson, C. J.: Distribution, nature, and origins of the $2400 \mathrm{BP}$ eruption products of Mount Meager, British Columbia, Linkages between magma chemistry and eruption behaviour, Geol. Surv. Can. Bull., 486, 1-27 1996.

Stewart, M.: Dacite Block and Ash Avalanche Hazards in Mountainous Terrain: $2360 \mathrm{yr}$ BP Eruption of Mount Meager, British Columbia, M.Sc. thesis, University of British Columbia, 2002.

Weichert, D., Horner, R. B., and Evans, S. G.: Seismic signatures of landslides: The 1990 Brenda Mine collapse and the 1965 Hope rockslides, Bull. Seismol. Soc. Am., 84, 1523-1532, 1994.

Westgate, J. A. and Dreimanis, A.: Volcanic ash layers of Recent age at Banff National Park, Alberta, Canada, Can. J. Earth Sci., 4, 155-161, 1967. 